\title{
The EANM practice guidelines for parathyroid imaging
}

\author{
Petra Petranović Ovčariček ${ }^{1,2}$. Luca Giovanella ${ }^{1,3,4}$ - Ignasi Carrió Gasset ${ }^{5}$ - Elif Hindié ${ }^{6}$ - Martin W. Huellner ${ }^{7}$. \\ Markus Luster ${ }^{1,8}$ - Arnoldo Piccardo $^{9}$ - Theresia Weber ${ }^{10}$ • Jean-Noël Talbot ${ }^{11}$ • Frederik Anton Verburg ${ }^{1,12}$
}

Received: 25 January 2021 / Accepted: 23 March 2021 / Published online: 10 April 2021

(C) The Author(s) 2021

\begin{abstract}
Introduction Nuclear medicine parathyroid imaging is important in the identification of hyperfunctioning parathyroid glands in primary hyperparathyroidism (pHPT), but it may be also valuable before surgical treatment in secondary hyperparathyroidism (sHPT). Parathyroid radionuclide imaging with scintigraphy or positron emission tomography (PET) is a highly sensitive procedure for the assessment of the presence and number of hyperfunctioning parathyroid glands, located either at typical sites or ectopically. The treatment of pHPT is mostly directed toward minimally invasive parathyroidectomy, especially in cases with a single adenoma. In experienced hands, successful surgery depends mainly on the exact preoperative localization of one or more hyperfunctioning parathyroid adenomas. Failure to preoperatively identify the hyperfunctioning parathyroid gland challenges minimally invasive parathyroidectomy and might require bilateral open neck exploration.

Methods Over a decade has now passed since the European Association of Nuclear Medicine (EANM) issued the first edition of the guideline on parathyroid imaging, and a number of new insights and techniques have been developed since. The aim of the present document is to provide state-of-the-art guidelines for nuclear medicine physicians performing parathyroid scintigraphy, single-photon emission computed tomography/computed tomography (SPECT/CT), positron emission tomography/computed tomography (PET/CT), and positron emission tomography/magnetic resonance imaging (PET/MRI) in patients with pHPT, as well as in those with sHPT.

Conclusion These guidelines are written and authorized by the EANM to promote optimal parathyroid imaging. They will assist nuclear medicine physicians in the detection and correct localization of hyperfunctioning parathyroid lesions.
\end{abstract}

Keywords Parathyroid scintigraphy $\cdot$ Hyperparathyroidism $\cdot\left[{ }^{99 \mathrm{~m}} \mathrm{Tc}\right] \mathrm{Tc}-\mathrm{MIBI} \cdot\left[{ }^{99 \mathrm{~m}} \mathrm{Tc}\right] \mathrm{Tc}$-tetrofosmin $\cdot \mathrm{SPECT} / \mathrm{CT}$. Dual-phase scintigraphy $\cdot$ Dual-tracer scintigraphy $\cdot{ }^{18} \mathrm{~F}$-labeled choline analogues $\cdot\left[{ }^{11} \mathrm{C}\right] \mathrm{CH} \cdot\left[{ }^{11} \mathrm{C}\right] \mathrm{MET} \cdot \mathrm{PET} / \mathrm{CT} \cdot \mathrm{Cervical}$ ultrasonography $\cdot 4 \mathrm{D}-\mathrm{CT} \cdot \mathrm{MRI}$

This article is part of the Topical Collection on Endocrinology

Frederik Anton Verburg

f.verburg@erasmusmc.nl

EANM Thyroid Committee, Vienna, Austria

2 Department of Oncology and Nuclear medicine, University Hospital Center "Sestre milosrdnice", Zagreb, Croatia

3 Clinic for Nuclear Medicine and Competence Centre for Thyroid Diseases, Imaging Institute of Southern Switzerland, Bellinzona, Switzerland

4 Clinic for Nuclear Medicine and Interdisciplinary Thyroid Centre, University Hospital and University of Zurich, Zurich, Switzerland

5 Department of Nuclear Medicine, Hospital Sant Pau and Autonomous University of Barcelona, Barcelona, Spain

6 Department of Nuclear Medicine, Bordeaux Hospital and University, Bordeaux, France
7 Department of Nuclear Medicine, University Hospital and University of Zurich, Zurich, Switzerland

8 Department of Nuclear Medicine, University Hospital Marburg, Marburg, Germany

9 Department of Nuclear Medicine, E.O. Ospedali Galliera, Genoa, Italy

10 Department of Endocrine Surgery, Katholisches Klinikum Mainz, Mainz, Germany

11 Nuclear Medicine, Hospital Tenon APHP and Sorbonne University, Paris, France

12 Department of Radiology and Nuclear Medicine, Erasmus MC, Rotterdam, The Netherlands 


\section{Preamble}

The European Association of Nuclear Medicine (EANM) is a professional non-profit medical association that facilitates communication worldwide among individuals pursuing clinical and research excellence in nuclear medicine. The EANM was founded in 1985.

These guidelines are intended to assist practitioners in providing appropriate nuclear medicine care for patients. They are not inflexible rules or requirements of practice and are not intended, nor should they be used, to establish a legal standard of care.

The ultimate judgment regarding the propriety of any specific procedure or course of action must be made by medical professionals taking into account the unique circumstances of each case. Thus, there is no implication that an approach differing from the guidelines, standing alone, is below the standard of care. To the contrary, a conscientious practitioner may responsibly adopt a course of action different from that set out in the guidelines when, in the reasonable judgment of the practitioner, such course of action is indicated by the condition of the patient, limitations of available resources, or advances in knowledge or technology subsequent to publication of the guidelines. The practice of medicine involves not only the science but also the art of dealing with the prevention, diagnosis, alleviation, and treatment of disease.

The variety and complexity of human conditions make it impossible to always reach the most appropriate diagnosis or to predict with certainty a particular response to treatment. Therefore, it should be recognized that adherence to these guidelines will not ensure an accurate diagnosis or a successful outcome.

All that should be expected is that the practitioner will follow a reasonable course of action based on current knowledge, available resources, and the needs of the patient to deliver effective and safe medical care. The sole purpose of these guidelines is to assist practitioners in achieving this objective.

\section{Introduction}

Primary hyperparathyroidism is an endocrine disorder caused by one or more hyperfunctioning parathyroid glands. The suspicion of pHPT is typically raised by the detection of hypercalcemia and/or its associated symptoms. Parathyroid hormone (PTH) serum concentration is elevated, or within normal limits but inappropriate considering the presence of hypercalcemia. A rare type of pHPT is normocalcemic hyperparathyroidism presenting with normal serum calcium levels but an elevated PTH concentration [1].

Primary hyperparathyroidism is the third most common endocrine disease [2], affecting women 2-3 times more often than men [3]. It is caused by the hyperfunction of one or more parathyroid glands, which are overproducing PTH. Hyperfunctioning parathyroid glands are solitary adenomas in the majority of cases. Approximately $15-20 \%$ of cases are caused by multiglandular disease (MGD) [4], i.e., multiple adenomas or hyperplasia, while parathyroid carcinoma accounts for less than $1 \%$ of cases. The majority of pHPT cases (95\%) occur sporadically, but approximately $5 \%$ are part of hereditary syndromes, such as multiple endocrine neoplasia types 1, 2, and 4 (MEN-1, MEN-2, and MEN-4) and hyperparathyroidism-jaw tumor syndrome, or as part of nonsyndromic familial pHPT [5].

Familial hypocalciuric hypercalcemia, a potential differential diagnosis to pHPT, has to be recognized as it usually does not require surgery.

Secondary hyperparathyroidism is a disorder characterized by increased serum PTH levels due to parathyroid gland hyperplasia, triggered by hypocalcemia, hyperphosphatemia, or decreased serum vitamin D concentration. The most common causes of sHPT are vitamin D deficiency and chronic renal disease. Sometimes pHPT and vitamin D deficiency occur simultaneously, which results in decreased or normal serum calcium levels. Rarer causes are long-term treatment with lithium or magnesium, intestinal malabsorption or malnutrition, or sunitinib treatment.

The therapy of sHPT depends on the primary cause. In the case of renal HPT, therapy mainly consists of a restriction of dietary intake together with medical treatment with calcimimetics, vitamin D analogues, and phosphorus binders [6]. Still, parathyroidectomy is required in patients with renal sHPT refractory to medical treatment, i.e., in approximately $15 \%$ of patients after 10 years and $38 \%$ of patients after 20 years of renal dialysis therapy [7].

Paraneoplastic hyperparathyroidism is rare. In most cases it is due to parathyroid hormone-related peptide (PTH-rp) production and the serum level of PTH is low in relation to hypercalcemia. In rare cases, the culprit cancer produces PTH or both PTH and PTH-rp, while no hyperfunctioning parathyroid gland is present [8]. Most commonly, the PTH-rp secreting malignancies include squamous cell carcinoma (lung, head and neck, cervix) and some other solid tumors.

Parathyroid glands are typically located along both thyroid lobes. The superior parathyroid glands develop from the 4 th pharyngeal pouch and descend with the thyroid. They are located dorsal to the middle and upper poles of the thyroid, and above the inferior thyroid artery. The inferior parathyroid glands develop from the 3 rd pouch and descend with the thymus to ultimately remain close to the lower thyroid pole, and more laterally [9]. Superior and inferior parathyroid glands have a different relationship to the recurrent laryngeal nerve, with the superior ones lying posterior to it, and the inferior ones anterior to it. 
The incidence of ectopic parathyroid glands is approximately $16 \%$ [10]. An ectopically located gland may be one of the four standard parathyroid glands or a supernumerary gland. Most individuals (84\%) have four parathyroid glands, two superior and two inferior glands, while supernumerary glands exist in 3 to $13 \%$ of individuals [11]. The total number of parathyroid glands in an individual with supernumerary glands may vary from 5 to 8 in number [12]. Rarely, in less than $3 \%$ of cases, individuals may have only 3 glands [11].

Acquired ectopy of upper parathyroid glands is frequently encountered along the tracheoesophageal groove or more rarely retroesophageally. They are usually in a lower position than expected (prolapsed glands) [13]. Moreover, ectopic glands can be located anywhere along the migratory path [14], from the carotid bifurcation to the pericardium. Ectopic sites, therefore, include but are not limited to, a high cervical position, the carotid sheath, an intrathyroidal location, intrathymic location, mediastinal location, or the paraesophageal region [15]. Very rarely, they can also be located in the pericardium [16, 17]. However, the most common location for ectopic upper parathyroid glands is along the esophagus, while ectopic lower parathyroid glands most often have an intrathymic location [9].

Histologically, parathyroid glands consist of a chief, oxyphil, transitional oxyphil, and water-clear cells. Chief cells are the most abundant cells [18]. They have a secretory function and are responsible for synthesizing and secreting PTH. Oxyphil cells are rich in mitochondria and their function is still unclear [19]. The function of water-clear cells is not clearly understood as well.

Owing to the abundance of mitochondria within the oxyphil cells, there is a high accumulation of $\left[{ }^{99 \mathrm{~m}} \mathrm{Tc}\right] \mathrm{Tc}$ MIBI and $\left[{ }^{99 \mathrm{~m}} \mathrm{Tc}\right] \mathrm{Tc}$-tetrofosmin in hyperfunctioning parathyroid glands.

Radionuclide parathyroid imaging reveals hyperfunctioning parathyroid glands located at typical sites as well as ectopically. Using planar scintigraphy or SPECT, sensitivity is greater for adenomas compared with hyperplasia. Hyperplastic parathyroid glands are usually smaller than adenomas, which is associated with decreased sensitivity of radionuclide imaging [20]. Other factors may also contribute to reduced sensitivity for MGD (e.g., tracer washout from some lesions in dual-phase imaging, the inhibitory effect of hypercalcemia, etc.). However, it is important to recognize MGD, as it holds implications for a successful surgery. Each subsequent surgery in a postoperative neck is technically challenging and carries an additional risk of complications, including failure to remove the culprit gland(s).

For the reasons stated above, it is necessary to identify the most sensitive and specific diagnostic procedure to detect hyperfunctioning parathyroid glands. The currently most widespread preoperative imaging procedure is the combination of $\left[{ }^{99 \mathrm{~m}} \mathrm{Tc}\right] \mathrm{Tc}-\mathrm{MIBI}$ scintigraphy and cervical ultrasonography
(cUS), yielding a sensitivity of $81-95 \%[21,22]$, which is mainly contributed by $\left[{ }^{99 \mathrm{~m}} \mathrm{Tc}\right] \mathrm{Tc}-\mathrm{MIBI}$ scintigraphy. Cervical ultrasonography can be combined with targeted fine-needle aspiration (FNA) cytology and detection of PTH in the aspirate (FNA-PTH) in order to increase specificity and confirm the diagnosis of hyperfunctioning parathyroid lesions in sonographically accessible locations [23]. Fine-needle aspiration cytology is recommended in highly selected cases, e.g., atypical cUS presentation and uninformative $\left[{ }^{99 \mathrm{~m}} \mathrm{Tc}\right] \mathrm{Tc}-\mathrm{MIBI}$. In case of negative standard imaging, second-line imaging may be performed, such as $\mathrm{N}-\left[\left({ }^{18} \mathrm{~F}\right)\right.$ fluoromethyl] $-2-\mathrm{hyd}$ rox y - N, N dimethylethanaminium $\left(\left[{ }^{18} \mathrm{~F}\right] \mathrm{FCH}\right.$ or $\left[{ }^{18} \mathrm{~F}\right]$ fluorocholine $)$ PET/CT, L- $\left[\right.$ methyl- $\left.{ }^{11} \mathrm{C}\right]$ methionine $\left(\left[{ }^{11} \mathrm{C}\right] \mathrm{MET}\right) \mathrm{PET} / \mathrm{CT}$, $\left[{ }^{11} \mathrm{C}\right] 2$-hydroxy-N,N,N-trimethylethanamium $\left(\left[{ }^{11} \mathrm{C}\right] \mathrm{CH}\right)$ $\mathrm{PET} / \mathrm{CT}$, so-called four-dimensional computed tomography (4D-CT), MRI, $\left[{ }^{18} \mathrm{~F}\right]$ fluorocholine PET/4D-CT or $\left[{ }^{18} \mathrm{~F}\right]$ fluorocholine PET/MRI. $\left[{ }^{18} \mathrm{~F}\right]$ fluorocholine PET/CT is also considered a potential "alternative" first-line method whenever possible, as it appears to be an effective technique even in patients with negative or equivocal standard imaging findings. It is particularly useful in patients with sHPT [24-26]. Before revision surgery and/or in the case of negative imaging techniques, invasive techniques, such as selective venous sampling or selective arteriography, may be performed.

\section{Goals}

The EANM practice guidelines for parathyroid imaging are written for nuclear medicine practitioners to promote the use of optimal parathyroid imaging based on current knowledge. The purpose of these recommendations is to assist in the performance, the correct interpretation, and reporting of the results of the parathyroid imaging.

\section{Background}

Primary hyperparathyroidism is defined as high serum PTH levels due to the presence of enlarged hyperfunctioning parathyroid gland(s). It is the most common cause of elevated calcium levels in the ambulatory setting [3], although calcemia in some cases may be normal. Rarely, PTH levels are normal with concomitant hypercalcemia. Primary hyperparathyroidism represents a considerable public health problem due to its high incidence and repercussions to patients' health. Therapy primarily consists of the surgical removal of the hyperfunctioning parathyroid gland(s) [27]. Symptomatic patients require treatment and generally undergo parathyroidectomy, which is the only definitive therapy. Surgery is also an important option in asymptomatic patients who can 
develop hypercalcemia and target organ involvement later in life [28]. If surgery is indicated, preoperative localization of the hyperfunctioning gland(s) allows for selective parathyroidectomy, reducing operation time, complications and hospitalization, improving postoperative recovery, and resulting in a better cosmetic outcome, and greater patient satisfaction $[29,30]$. Nuclear medicine techniques and cUS are crucial in identifying and localizing hyperfunctioning parathyroid glands. Both methods have advantages, as well as limitations. The advantage of radionuclide parathyroid imaging over cUS lies in the identification of ectopic glands [31], as well as in easier recognition of posteriorly located upper glands [32]. Arguably it also enables an easier recognition of typically located hyperfunctioning parathyroid glands in the background of thyroiditis. It is known that thyroiditis is usually followed by enlarged lymph nodes that are sometimes imitating hyperfunctioning parathyroid glands on cUS [33]. On the other hand, suspected hyperfunctioning parathyroid glands in the neck on radionuclide imaging can be further examined with cUS in order to avoid false-positive results. In patients with multinodular goiter, $\left[{ }^{99 \mathrm{~m}} \mathrm{Tc}\right] \mathrm{Tc}-\mathrm{MIBI}$ scintigraphy might be false negative, and cUS is mandatory [34]. In these cases, dual-tracer methods and $\left[{ }^{18} \mathrm{~F}\right]$ fluorocholine PET/CT are useful as well [35]. Additionally, cUS is a valuable method for excluding coexisting thyroid pathology in most cases, although in toxic multinodular goiter or thyroid remnants after hemithyroidectomy dual-tracer methods are helpful as well. If a hyperfunctioning parathyroid gland is identified during cUS, radionuclide imaging may still prove to be useful because of possible undetected MGD, as well as ectopic glands. For the reasons stated above, in addition to radionuclide parathyroid gland imaging, using SPECT and/or PET tracers, these guidelines will also discuss ultrasound of the parathyroid glands as the main complementary diagnostic imaging modality. Additionally, the use of 4D CT, MRI, and invasive techniques in identifying abnormal parathyroid glands will be addressed in brief.

\section{Indications}

Radionuclide parathyroid imaging is used for the localization of one or more hyperfunctioning parathyroid glands in patients with $\mathrm{pHPT}$, and not for the diagnosis of hyperparathyroidism (HPT). It might be also valuable before surgical treatment in SHPT due to possible detection of ectopic and supernumerary glands, as well as a parathyroid gland with the lowest $\left[{ }^{99 \mathrm{~m}} \mathrm{Tc}\right] \mathrm{Tc}-\mathrm{MIBI}$ uptake which may be partially autografted or preserved $[36,37]$. Périé et al. recommend a combination of cUS and dual-tracer scintigraphy for routine use to localize hyperfunctioning parathyroid glands in patients with renal HPT undergoing surgical treatment [38]. However, surgeons usually do not order $\left[{ }^{99 \mathrm{~m}} \mathrm{Tc}\right] \mathrm{Tc}-\mathrm{MIBI}$ scintigraphy before primary surgery for renal hyperparathyroidism, and bilateral open neck exploration is considered in these patients. Still, radionuclide imaging may be helpful in cases of revision surgery. In such circumstances, a combination of imaging modalities is often required [37].

Radionuclide imaging is useful preoperatively to guide the surgeon toward the exact location of one or more hyperfunctioning parathyroid glands, especially in the case of ectopic glands that cannot be visualized with cUS. Correct preoperative localization may shorten the duration of surgery, which nowadays mostly consists of minimally invasive parathyroidectomy combined with intraoperative PTH determination, particularly in single-gland disease. In the past, bilateral open neck exploration was the standard surgical approach. However, both techniques are appropriate and accomplish high cure rates [39]. Excision of all hyperfunctioning parathyroid glands is pivotal for successful parathyroidectomy.

Radionuclide parathyroid imaging is especially useful in patients with recurrent disease because the second operation is technically more challenging than the first one, and hence a precise preoperative localization of hyperfunctioning parathyroid gland(s) is important.

Radionuclide parathyroid imaging is also useful in conjunction with cUS, foremost in patients with hereditary disorders, such as MEN-1, MEN-2, and MEN-4, although sensitivity for hyperplasia is lower compared with sporadic adenoma. In this context, PET/CT might be preferred, owing to its higher spatial resolution [40]. The identification of hyperfunctioning glands can be supported by a $\gamma$-probe during surgery, especially in patients who underwent previous surgical treatment [41].

\section{Precautions}

It is necessary to exclude pregnancy in women of childbearing age.

In pregnant patients, radionuclide imaging should only be performed if deemed absolutely necessary, as decided by a multidisciplinary team. Otherwise, it should be postponed after pregnancy. Instead, cUS and MRI may be preferred in this case.

For more information, we advise to consult the American College of Radiology (ACR) Practice Guideline for imaging pregnant or potentially pregnant adolescents and women with ionizing radiation [42].

In breastfeeding women, it is recommended to consult the International Commission on Radiological Protection (ICRP) Publication 128: Radiation Dose to Patients from Radiopharmaceuticals: A Compendium of Current Information Related to Frequently Used Substances [43]. When using ${ }^{99 \mathrm{~m}} \mathrm{Tc}$-labeled radiopharmaceuticals, interruption of breastfeeding is not essential if free pertechnetate is absent 
in the radiopharmaceutical. However, a pause of $24 \mathrm{~h}$ during which expressed feeds are discarded is recommended in some summaries of product characteristics ( $\mathrm{SmPC}$ ) of ${ }^{99 \mathrm{~m}} \mathrm{Tc}$ labeled radiopharmaceuticals with marketing authorization. In the case of $\mathrm{Na}\left[{ }^{99 \mathrm{~m}} \mathrm{Tc}\right] \mathrm{TcO}_{4}$, which is used for subtraction imaging, a $12 \mathrm{~h}$ pause is recommended. For $\mathrm{Na}\left[{ }^{123} \mathrm{I}\right] \mathrm{I}$, breastfeeding interruption for $>3$ weeks is advised due to the risk of other iodine isotope contamination. However, if the product has high purity ( $>99.65 \%$ ), the pause may be shorter. In the SmPC of some $\mathrm{Na}\left[{ }^{123} \mathrm{I}\right] \mathrm{I}$ preparations, $1-$ 3 days pause is recommended, and breastfeeding can be restarted when the activity level in the milk has reduced so that it will not result in a radiation dose to the child greater than $1 \mathrm{mSv}$. To be on the safe side we recommend a 3-day pause. It is not known whether $\left[{ }^{11} \mathrm{C}\right] \mathrm{CH},{ }^{18} \mathrm{~F}$-labeled choline analogues, and $\left[{ }^{11} \mathrm{C}\right] \mathrm{MET}$ are excreted in breast milk. Still, for ${ }^{11} \mathrm{C}$-labeled radiopharmaceuticals, interruption is not essential due to their short physical half-life. No recommendation concerning the pause in lactation for ${ }^{18} \mathrm{~F}$-labeled choline analogues is available in ICRP publication 128, but it may be found in the SmPC of the ${ }^{18} \mathrm{~F}$-labeled choline analogues preparation with a marketing authorization. A $12 \mathrm{~h}$ pause is recommended in some SmPCs.

\section{Qualifications and responsibilities of personnel}

Nuclear medicine physicians, technicians and all other staff involved in performing and reporting parathyroid radionuclide imaging should be qualified according to applicable laws and regulations, and individual responsibilities should be clearly documented.

\section{Useful clinical information for optimal imaging and interpretation}

A request for parathyroid radionuclide imaging must be submitted to a nuclear medicine physician. It should provide sufficient data to allow the responsible nuclear medicine physician to assess the indication for the scan adequately, as well as to interpret the images.

The patient is also questioned (if possible) for relevant information that may help interpret the findings.

In pre-imaging reporting it is useful to document:

1. Serum intact PTH level and either albumin corrected or ionized calcium and serum 25-hydroxy vitamin D level (mandatory)

2. Serum phosphorus, 24-h urinary calcium levels, creatinine, markers of bone turnover, e.g., bone-specific alkaline phosphatase (optional)
3. Results of cervical US, including the thyroid and parathyroid glands

4. Results of other imaging modalities, such as 4D-CT, and MRI, if any

5. History of any prior neck and/or thoracic surgery

6. History of malignancy, because of possible tracer accumulation in neoplastic tissue

7. History of recent nuclear medicine procedures

8. Recent iodine intake (e.g., intravenous contrast medium, iodine-containing medication ...) or thyroid hormone replacement therapy in case of subtraction study with $\mathrm{Na}\left[{ }^{99 \mathrm{~m}} \mathrm{Tc}\right] \mathrm{TcO}_{4}$ or $\mathrm{Na}\left[{ }^{123} \mathrm{I}\right] \mathrm{I}$, or therapy with cinacalcet and other calcimimetics in case of $\left[{ }^{99 \mathrm{~m}} \mathrm{Tc}\right] \mathrm{Tc}-\mathrm{MIBI}$ imaging

9. Use of calcium channel blockers if scintigraphy is performed with $\left[{ }^{99 \mathrm{~m}} \mathrm{Tc}\right] \mathrm{Tc}-\mathrm{MIBI}$

Patients should be provided with information on how the examination is performed and the estimated duration. The patient should be advised to stay calm during image acquisition. In rare cases, e.g., in patients with severe claustrophobia, sedation may be helpful.

Patients may eat, drink, and take most of the necessary medications. However, active D vitamin analogues and calcimimetics may decrease $\left[{ }^{99 \mathrm{~m}} \mathrm{Tc}\right] \mathrm{Tc}-\mathrm{MIBI}$ uptake [44]. If possible, these should be paused for 2 weeks before scintigraphy [36].

Calcium channel blockers may reduce uptake of $\left[{ }^{99 \mathrm{~m}} \mathrm{Tc}\right] \mathrm{Tc}-\mathrm{MIBI}$ as well [45]. Friedman et al. in a retrospective study found that the odds ratio for a negative scan is 2.88 in patients taking calcium channel blockers compared with those without such medication (OR 2.88, 95\% CI, 1.03$8.10 ; p=0.045$ ). Still, further studies are necessary to confirm the reversibility of this finding, and to determine the appropriate withdrawal period.

In a dual-tracer study, the thyroid scan should be performed without iodine saturation. Many factors can influence thyroid uptake of subtraction radiopharmaceuticals [46]. Dual-phase $\left[{ }^{99 \mathrm{~m}} \mathrm{Tc}\right] \mathrm{Tc}-\mathrm{MIBI}$ scintigraphy, instead of dual-tracer scintigraphy, is recommended for patients on thyroid hormone replacement therapy to avoid therapy withdrawal and subsequent development of hypothyroidism.

Currently, no standardized patient preparation or image acquisition guidelines exist for parathyroid imaging with PET tracers. In the case of radiolabelled choline, vigorous exercise may increase muscle uptake of the radiopharmaceutical, so it is advisable to avoid such before scanning [47].

If a diagnostic $\mathrm{CT}$ scan with iodinated contrast medium is required, it is important to ask the patient about possible allergies to iodinated contrast medium as well as to ascertain an adequate kidney and thyroid function; for more information, we advise to consult the European Society of Urogenital Radiology (ESUR) guidelines on contrast media: Post- 
contrast acute kidney injury_-Part 1: Definition, clinical features, incidence, role of contrast medium and risk factors; Post-contrast acute kidney injury-Part 2: risk stratification, role of hydration and other prophylactic measures, patients taking metformin and chronic dialysis patients $[48,49]$.

\section{Scintigraphy and SPECT}

Parathyroid gland scintigraphy has involved many different radiotracers used with different protocols over the past decades.

In the 1980 s, parathyroid gland scintigraphy was performed with $\left[{ }^{201} \mathrm{Tl}\right]$ thallous-chloride $\left(\left[{ }^{201} \mathrm{Tl}\right] \mathrm{TlCl}\right)$ in combination with $\left[{ }^{99 \mathrm{~m}} \mathrm{Tc}\right]$ Pertechnetate $\left(\left[{ }^{99 \mathrm{~m}} \mathrm{Tc}\right] \mathrm{NaTcO}_{4}\right)$ as a dualtracer method. The success rate in operated patients was comparably good, reaching 92\% [50]. However, $\left[{ }^{201} \mathrm{Tl}\right] \mathrm{TlCl}$ has poor physical characteristics as an imaging agent, due to suboptimal photon energy $(69-81 \mathrm{keV})$. Additionally, it has a long physical half-life $(73 \mathrm{~h}$ ) and thus results in a nowadays unacceptably high whole-body radiation exposure. $\left[{ }^{201} \mathrm{Tl}\right] \mathrm{TlCl}$ should no longer be used for parathyroid imaging. Furthermore, it is a cyclotron-produced radionuclide, and as such relatively expensive. In 1989, Coakley et al. reported the use of $\left[{ }^{99 m} \mathrm{Tc}\right] \mathrm{Tc}-\mathrm{MIBI}$ for parathyroid localization, revealing better imaging characteristics of this tracer compared with $\left[{ }^{201} \mathrm{Tl}\right] \mathrm{TlCl}$ [51]. Eventually, $\left[{ }^{201} \mathrm{Tl}\right] \mathrm{TlCl}$ was replaced with ${ }^{99 \mathrm{~m}}$ Tc-labeled tracers of better physical characteristics: more favorable energy $(140 \mathrm{keV})$ and shorter physical half-life $(6 \mathrm{~h})$, resulting in lower radiation exposure. Besides, ${ }^{99 \mathrm{~m}} \mathrm{Tc}$ is ubiquitously available and comparatively inexpensive.

More widespread use of $\left[{ }^{99 \mathrm{~m}} \mathrm{Tc}\right] \mathrm{Tc}-\mathrm{MIBI}$ and $\left[{ }^{99 \mathrm{~m}} \mathrm{Tc}\right] \mathrm{Tc}$ tetrofosmin began in the 1990s. The former was used in the single-tracer and dual-tracer methods, while the latter was used mainly in a dual-tracer method in combination with $\mathrm{Na}\left[{ }^{99 \mathrm{~m}} \mathrm{Tc}\right] \mathrm{TcO}_{4}$ or $\mathrm{Na}\left[{ }^{123} \mathrm{I}\right] \mathrm{I}$.

\section{Radiopharmaceuticals targeting parathyroid glands}

\section{$\left[{ }^{99 \mathrm{~m}} \mathrm{Tc}\right] \mathrm{Tc}$-hexakis-(2-methoxy-2-isobutyl isonitrile) $\left({ }^{99 \mathrm{~m}} \mathrm{Tc}\right]$ Tc-MIBI)}

$\left[{ }^{99 \mathrm{~m}} \mathrm{Tc}\right] \mathrm{Tc}-\mathrm{MIBI}$ is the most widely used radiopharmaceutical for parathyroid scintigraphy. It is a lipophilic cationic complex that accumulates in hyperfunctioning parathyroid glands due to their increased number of mitochondria [52], which is mainly related to the number of oxyphil cells [53]. Its uptake and retention depend also on the cell cycle phase, parathyroid blood supply, capillary permeability, serum calcium level, expression of P-glycoprotein, and multidrug resistance (MDR) associated protein [54].

$\left[{ }^{99 \mathrm{~m}} \mathrm{Tc}\right] \mathrm{Tc}-\mathrm{MIBI}$ has a greater uptake per gram of parathyroid tissue than per gram of thyroid tissue [55]. Additionally, it usually washes out faster from the thyroid than from the hyperfunctioning parathyroid, making it convenient for the single-tracer dual-phase method.

However, not all hyperfunctioning parathyroid glands retain $\left[{ }^{99 m} \mathrm{Tc}\right] \mathrm{Tc}-\mathrm{MIBI}$ and thyroid tissue sometimes does not rapidly washout [56]. Therefore, in some cases, other protocols might be helpful. In the case of a rapid parathyroid washout, it would be reasonable to perform additional images between the standard early and late phase ones. Alternatively, dynamic imaging may be used. On the other hand, in the case of a slow thyroidal washout, subtraction imaging may be helpful.

$\left[{ }^{99 \mathrm{~m}} \mathrm{Tc}\right] \mathrm{Tc}-\mathrm{MIBI}$ SPECT/CT scintigraphy is the current standard method for detecting hyperfunctioning parathyroid glands, with a reported patient-based and lesion-based pooled detection rate (DR) of $88 \%$ in a meta-analysis of twenty-three papers including 1236 patients with pHPT [57]. Furthermore, it was shown to be a cost-effective technique [58].

However, its sensitivity is significantly lower in the case of MGD compared with single-gland disease [59, 60], which is a known issue also with other imaging modalities. Nichols et al. in a study of 651 patients with HPT (20\% with MGD, and $80 \%$ with single-gland disease) who underwent preoperative dual-tracer $\left[{ }^{99 \mathrm{~m}} \mathrm{Tc}\right] \mathrm{Tc}-\mathrm{MIBI} / \mathrm{Na}\left[{ }^{99 \mathrm{~m}} \mathrm{Tc}\right] \mathrm{TcO}_{4}$ scintigraphy found the sensitivity of this method to be $61 \%$ for MGD, vs. $97 \%$ for single-gland disease [60]. Medas et al. in a study that included 212 patients with HPT (8\% with MGD, $91.5 \%$ with single-gland disease, and $0.5 \%$ unknown) reported a sensitivity of $\left[{ }^{99 \mathrm{~m}} \mathrm{Tc}\right] \mathrm{Tc}-\mathrm{MIBI}$ for MGD of $26.7 \%$ vs. $92.6 \%$ for single-gland disease [59].

The administered intravenous radioactivity in adults ranges from 400 to $900 \mathrm{MBq}$, depending on the patient's body mass, whether or not SPECT is scheduled, and local regulations (Table 1). Whenever SPECT imaging is combined with CT, care should be taken to use the lowest CT dose that is compatible with the purpose.

\section{[99m Tc]Tc-1,2-bis[bis (2-ethoxyethyl) phosphino] ethane) ([ $\left.{ }^{99 \mathrm{~m}} \mathrm{Tc}\right]$ Tc-tetrofosmin)}

$\left[{ }^{99 \mathrm{~m}} \mathrm{Tc}\right] \mathrm{Tc}$-tetrofosmin is a lipophilic cation that localizes in thyroid and parathyroid tissue. Because there is no differential washout between these tissues, it is suitable only for a dualtracer subtraction method. The mechanism of uptake is similar to $\left[{ }^{99 \mathrm{~m}} \mathrm{Tc}\right] \mathrm{Tc}-\mathrm{MIBI}$. It diffuses passively through the cell membrane and accumulates in mitochondria of parathyroid lesions [61]. The intravenously administered activity in adults ranges from 400 to $900 \mathrm{MBq}$, depending on the patient's body mass, whether or not SPECT is scheduled, and local regulations.

However, its use in parathyroid imaging is limited, despite an overall good performance similar to that of $\left[{ }^{99 \mathrm{~m}} \mathrm{Tc}\right] \mathrm{Tc}$ MIBI [56, 62, 63], owing, e.g., to the need for the dual- 
Table 1 Radiopharmaceuticals for parathyroid imaging. Characteristics, recommended activity range, and effective doses

\begin{tabular}{|c|c|c|c|c|c|c|}
\hline Radiopharmaceutical & $\begin{array}{l}\text { Administration } \\
\text { route }\end{array}$ & $\begin{array}{l}\text { Administered activity } \\
\text { in adults }(\mathrm{MBq})\end{array}$ & $\begin{array}{l}\text { Photopeak } \\
\text { energy }(\mathrm{keV})\end{array}$ & $\begin{array}{l}\text { Physical } \\
\text { half-life }\end{array}$ & $\begin{array}{l}\text { Effective dose per } \\
\text { activity unit (mSv/MBq) }\end{array}$ & $\begin{array}{l}\text { Effective dose for the upper } \\
\text { administered activity (mSv) }\end{array}$ \\
\hline $\mathrm{Na}\left[{ }^{99 \mathrm{~m}} \mathrm{Tc}\right] \mathrm{TcO}_{4}$ & i.v. & $74-150$ & 140 & $6.04 \mathrm{~h}$ & $0.0159 *$ & 2.4 \\
\hline$\left[{ }^{99 \mathrm{~m}} \mathrm{Tc}\right] \mathrm{Tc}-\mathrm{MIBI}$ & i.v. & $400-900$ & 140 & $6.04 \mathrm{~h}$ & $0.00703 *$ & 6.3 \\
\hline$\left[{ }^{99 \mathrm{~m}} \mathrm{Tc}\right] \mathrm{Tc}$-tetrofosmin & i.v. & $400-900$ & 140 & $6.04 \mathrm{~h}$ & $0.00629 *$ & 5.7 \\
\hline $\mathrm{Na}\left[{ }^{123} \mathrm{I}\right] \mathrm{I}$ & o.a. (or i.v.) & $7.4-14.8$ & 159 & $13.2 \mathrm{~h}$ & $\begin{array}{l}0.108 * \text { (thyroid uptake } \\
15 \% \text { ) }\end{array}$ & 1.6 (thyroid uptake $15 \%$ ) \\
\hline$\left[{ }^{18} \mathrm{~F}\right] \mathrm{FCH}$ & i.v. & $100-300$ & 511 & $110 \mathrm{~min}$ & $0.020 * *$ & 6.0 \\
\hline$\left[{ }^{11} \mathrm{C}\right] \mathrm{MET}$ & i.v. & $370-1100$ & 511 & $20.3 \mathrm{~min}$ & $0.00549 *$ & 6.0 \\
\hline$\left[{ }^{11} \mathrm{C}\right] \mathrm{CH}$ & i.v. & $200-650$ & 511 & $20.3 \mathrm{~min}$ & $0.0044 * * *$ & 2.9 \\
\hline
\end{tabular}

i.v., intravenous; o.a.,oral administration, $*$ [163],** [164],*** [165]

tracer acquisition as well as local licensing and reimbursement issues.

\section{Subtraction radiopharmaceuticals}

\section{$\left[{ }^{99 m} \mathrm{Tc}\right]$ pertechnetate $\left(\mathrm{Na}\left[{ }^{99 m} \mathrm{Tc}\right] \mathrm{TcO}_{4}\right)$}

${ }^{99 \mathrm{~m}} \mathrm{Tc}$ has a physical half-life of $6 \mathrm{~h}$ and emits gamma rays of $140 \mathrm{keV} . \mathrm{Na}\left[{ }^{99 \mathrm{~m}} \mathrm{Tc}\right] \mathrm{TcO}_{4}$ is used in the dual-tracer method as it is taken up by functioning thyroid cells. The $\mathrm{Na}\left[{ }^{99 \mathrm{~m}} \mathrm{Tc}\right] \mathrm{TcO}_{4}$ image is subtracted from the $\left[{ }^{99 \mathrm{~m}} \mathrm{Tc}\right] \mathrm{Tc}-$ MIBI / [ $\left.{ }^{99 \mathrm{~m}} \mathrm{Tc}\right] \mathrm{Tc}$-tetrofosmin image, thus revealing hyperfunctioning parathyroid glands.

For further details on administered activity and image acquisition, please refer also to the EANM practice guideline/ SNMMI procedure standard for RAIU and thyroid scintigraphy [46]. The administered activity depends mainly on which tracer is applied first, i.e., if the thyroid study is performed before or after the $\left[{ }^{99 \mathrm{~m}} \mathrm{Tc}\right] \mathrm{Tc}-\mathrm{MIBI} /\left[{ }^{99 \mathrm{~m}} \mathrm{Tc}\right] \mathrm{Tc}$-tetrofosmin scan. If imaging starts with $\mathrm{Na}\left[{ }^{99 \mathrm{~m}} \mathrm{Tc}\right] \mathrm{TcO}_{4}$ scintigraphy, lower activities are required, i.e., 74-111 MBq compared with $150 \mathrm{MBq}$ if the thyroid scan is performed after the $\left[{ }^{99 \mathrm{~m}} \mathrm{Tc}\right] \mathrm{Tc}-\mathrm{MIBI}$ scan.

\section{$\left[{ }^{123} \mathrm{I}\right]$ sodium-iodide $\left(\mathrm{Na}\left[{ }^{123} \mathrm{I}\right] \mathrm{I}\right)$}

${ }^{123} \mathrm{I}$ has a half-life of $13 \mathrm{~h}$ and emits gamma radiation of $159 \mathrm{keV} . \mathrm{Na}\left[{ }^{123} \mathrm{I}\right] \mathrm{I}$ is trapped but also organified by functioning thyroid tissue. $\mathrm{Na}\left[{ }^{123} \mathrm{I}\right] \mathrm{I}$ is used in the dual-tracer method for subtraction purposes and provides good quality images. The $\mathrm{Na}\left[{ }^{123} \mathrm{I}\right] \mathrm{I}$ image is subtracted from a $\left[{ }^{99 \mathrm{~m}} \mathrm{Tc}\right] \mathrm{Tc}-\mathrm{MIBI} /$ $\left[{ }^{99 \mathrm{~m}} \mathrm{Tc}\right] \mathrm{Tc}$-tetrofosmin image for easier visualization of remaining hyperfunctioning parathyroid gland tissue. Disadvantages are its higher price compared with $\mathrm{Na}\left[{ }^{99 \mathrm{~m}} \mathrm{Tc}\right] \mathrm{TcO}_{4}$ and the $2 \mathrm{~h}$ waiting time between administration of the radiopharmaceutical and acquisition of the scan. For further information on this radiopharmaceutical, we refer to the EANM practice guideline/SNMMI procedure standard for RAIU and thyroid scintigraphy [46].

\section{Acquisition}

\section{Dual-phase parathyroid scan}

$\left[{ }^{99 m} \mathrm{Tc}\right] \mathrm{Tc}-\mathrm{MIBI}$ scintigraphy is performed at two time points, i.e., at $10-15 \mathrm{~min}$ and $90-150 \mathrm{~min}$ after intravenous administration of the radiopharmaceutical. The administered activity ranges from approximately 400 to $900 \mathrm{MBq}$, depending on the patient's body mass, whether or not SPECT is scheduled, and local regulations. Imaging is performed using large fieldof-view gamma cameras with low-energy, high resolution (LEHR) collimators. The energy window should be in the range of $140 \pm 10 \mathrm{keV}$ and a matrix size of $128 \times 128$ or better $256 \times 256$ should be employed. The entire neck and the chest down to the base of the heart should be included in the field of view. It is possible to use planar images in anterior and right and left anterolateral positions, but SPECT images, especially when fused with a simultaneously acquired CT, are superior for anatomical localization of parathyroid tissue [64], especially in case of ectopic glands and altered neck anatomy [65].

SPECT/CT with $\left[{ }^{99 \mathrm{~m}} \mathrm{Tc}\right] \mathrm{Tc}-\mathrm{MIBI}$ is superior to planar or stand-alone SPECT studies and dual-phase acquisition is more accurate than single-phase acquisition [66]. Therefore, it is recommended to perform at least one SPECT(/CT) study covering the area between the skull base and the heart base.

\section{Dual-tracer parathyroid scan}

$\left[{ }^{99 \mathrm{~m}} \mathrm{Tc}\right] \mathrm{Tc}-\mathrm{MIBI}$ usually has a differential washout between the thyroid and parathyroid, so it is used as the single tracer of dual-phase parathyroid scintigraphy in many nuclear medicine departments. However, sometimes the tracer washes out rapidly from the parathyroid or is retained in the thyroid, especially in thyroid nodules. In such cases, the use of the dualtracer method may be helpful. 
Dual-tracer $\left[{ }^{99 \mathrm{~m}} \mathrm{Tc}\right] \mathrm{Tc}-\mathrm{MIBI} / \mathrm{Na}\left[{ }^{99 \mathrm{~m}} \mathrm{Tc}\right] \mathrm{TcO}{ }_{4}$ protocol Either tracer, $\left[{ }^{99 \mathrm{~m}} \mathrm{Tc}\right] \mathrm{Tc}-\mathrm{MIBI}$ or $\mathrm{Na}\left[{ }^{99 \mathrm{~m}} \mathrm{Tc}\right] \mathrm{TcO}_{4}$ can be injected first. The administered activity of $\mathrm{Na}\left[{ }^{99 \mathrm{~m}} \mathrm{Tc}\right] \mathrm{TcO}_{4}$ is $74-$ $111 \mathrm{MBq}$ if the protocol starts with thyroid imaging. For further details, please refer to the EANM practice guideline/ SNMMI procedure standard for RAIU and thyroid scintigraphy [46]. $150 \mathrm{MBq}$ of activity is used if thyroid imaging is performed after the $\left[{ }^{99 \mathrm{~m}} \mathrm{Tc}\right] \mathrm{Tc}-\mathrm{MIBI}$ scan.

$\mathrm{Na}\left[{ }^{99 \mathrm{~m}} \mathrm{Tc}^{\mathrm{T}}\right] \mathrm{TcO}_{4}$ images are obtained 20-30 min after administration of the radiopharmaceutical, while $\left[{ }^{99 \mathrm{~m}} \mathrm{Tc}\right] \mathrm{Tc}-$ MIBI images are obtained $10-15$ min after injection. Images are inspected visually, normalized, and $\mathrm{Na}\left[{ }^{99 \mathrm{~m}} \mathrm{Tc}\right] \mathrm{TcO}_{4}$ images are either digitally or cognitively subtracted from the $\left[{ }^{99 \mathrm{~m}} \mathrm{Tc}\right] \mathrm{Tc}-\mathrm{MIBI}$ images. The following images are obtained: - a large field of view of the neck and mediastinum (from the skull base to the heart base); - a pinhole view of the thyroid bed region; and a SPECT(/CT) acquisition whenever available.

In order to reduce administered activities and radiation exposure, a waiting time of 2-3 days between tracers may be recommended.

Imaging is performed using a large field-of-view gamma camera with LEHR collimators, a matrix size of $128 \times 128$ or $256 \times 256$, and a $15 \%$ or $20 \%$ energy window centered at the $140 \mathrm{keV}\left({ }^{99 \mathrm{~m}} \mathrm{Tc}\right)$ photon peak.

Dual-tracer [ $\left.{ }^{99 \mathrm{~m}} \mathrm{Tc}\right] \mathrm{Tc}-\mathrm{MIBI} / \mathrm{Na}\left[{ }^{123} \mathrm{I}\right] /$ protocol $\mathrm{Na}\left[{ }^{123} \mathrm{I}\right] \mathrm{I}$ is first administered orally or intravenously, and $\left[{ }^{99 \mathrm{~m}} \mathrm{Tc}\right] \mathrm{Tc}-\mathrm{MIBI}$ is injected $2 \mathrm{~h}$ later. $\mathrm{Na}\left[{ }^{123} \mathrm{I}\right] \mathrm{I}$ and $\left[{ }^{99 \mathrm{~m}} \mathrm{Tc}\right] \mathrm{Tc}-\mathrm{MIBI}$ images are acquired simultaneously, starting 5 min after injection of $\left[{ }^{99 \mathrm{~m}} \mathrm{Tc}\right] \mathrm{Tc}-\mathrm{MIBI}$. Images are inspected visually, normalized to thyroid counts, and $\mathrm{Na}\left[{ }^{123} \mathrm{I}\right] \mathrm{I}$ images are subtracted from the $\left[{ }^{99 \mathrm{~m}} \mathrm{Tc}\right] \mathrm{Tc}-\mathrm{MIBI}$ images. The following images are obtained: - a large field of view of the neck and mediastinum (from the skull base to the heart base); - a pinhole view of the thyroid bed region; - a SPECT(/CT) acquisition when available [67-69].

Imaging is performed with a large field-of-view gamma camera equipped with LEHR collimators. A matrix size of $128 \times 128$ or $256 \times 256$ is recommended. For simultaneous acquisition, a $10 \%$ energy window centered on the $159 \mathrm{keV}$ is recommended for $\left.\mathrm{Na}^{[123} \mathrm{I}\right] \mathrm{I}$ and a $15-20 \%$ window centered around $140 \mathrm{keV}$ for [ $\left.{ }^{99 \mathrm{~m}} \mathrm{Tc}\right] \mathrm{Tc}-\mathrm{MIBI}$. Alternatively, symmetric and asymmetric windows can be used $(140 \mathrm{keV} \pm 7 \%$ for $\left[{ }^{99 \mathrm{~m}} \mathrm{Tc}\right] \mathrm{Tc}-\mathrm{MIBI}$ and $159 \mathrm{keV}-4 \% ;+10 \%$ for $\left.\mathrm{Na}\left[{ }^{123} \mathrm{I}\right] \mathrm{I}\right)[70]$. For $\mathrm{Na}\left[{ }^{123} \mathrm{I}\right] \mathrm{I}$ thyroid imaging, it is also possible to use a dedicated thyroid camera with a small field-of-view.

In both dual-tracer protocols images are subtracted at the point of similar activity of $\left[{ }^{99 \mathrm{~m}} \mathrm{Tc}\right] \mathrm{Tc}-\mathrm{MIBI}$ in the thyroid gland and surrounding soft tissue.

Dual-tracer scintigraphy with subtraction imaging has an excellent performance in the detection and localization of hyperfunctioning parathyroid glands [71]. Woods et al. in a recent study reported high sensitivity and specificity for subtraction SPECT/CT (95\% and 89\%, respectively) [72]. The positive predictive value (PPV) and negative predictive value were $97 \%$ and $83 \%$, respectively. The accuracy in detecting and localizing parathyroid adenomas were $94 \%$ and $92 \%$, respectively. However, this technique adds additional radiation exposure to the thyroid; it might take additional time and is more expensive compared with a single-tracer method, although some institutions are trying to reduce administered activity and procedure length.

\section{Image analysis}

In dual-phase scintigraphy, early and delayed images are inspected visually. Increased or sustained uptake on the delayed $\left[{ }^{99 \mathrm{~m}} \mathrm{Tc}\right] \mathrm{Tc}-\mathrm{MIBI}$ image, compared with the early image, is considered a positive finding for a hyperfunctioning parathyroid gland. However, some glands show a fast washout and might not be identified clearly on delayed images. A fast clearance is more common in hyperplastic glands. SPECT images may reveal parathyroid glands that are not seen on planar images. Additionally, SPECT/CT imaging provides a superior anatomic localization of lesions.

In subtraction scanning, images need to be inspected visually before and after subtraction. Focal accumulation of radiopharmaceutical adjacent to the thyroid persisting after subtraction is suspicious for a hyperfunctioning parathyroid gland in loco typico; ectopic focal uptake is suspicious for an ectopic parathyroid lesion. As stated above, SPECT and SPECT/CT yield an increased sensitivity, specificity, and more precise anatomic localization compared with planar images.

The CT part of the study should be also analyzed for important findings, even without corresponding tracer uptake.

False-positive and false-negative results are occasionally encountered. The most common causes of false-positive results are inflammatory thyroiditis, cervical lymphadenopathy, and thyroid nodules (benign and malignant) behaving like parathyroid adenomas (in a single-tracer protocol) [73]. False-negative results usually occur due to small-sized hyperfunctioning glands [73], a lack of oxyphil cells [74], parathyroid hyperplasia, multiglandular disease, and high expression of P-glycoprotein [75].

\section{Positron emission tomography}

The higher resolution of PET/CT imaging could improve the detection of the smallest pathological glands, not visualized by SPECT(/CT). It is recommended to use the scanner with the highest system sensitivity and reconstruction protocols optimized for small lesion detection (BSREM instead of OSEM). Whenever PET imaging is combined with CT, care should be taken to use the lowest $\mathrm{CT}$ dose that is compatible 
with the purpose. Several different tracers have been studied with different protocols and results.

Currently, no standardized image acquisition guidelines exist for PET tracers for parathyroid imaging.

\section{Radiopharmaceuticals}

\section{${ }^{18}$ F-labeled choline analogues}

Choline is a cellular proliferation marker. The mechanism of uptake of ${ }^{18} \mathrm{~F}$-labeled or ${ }^{11} \mathrm{C}$-labeled choline analogues is not fully understood. As choline is a precursor of phosphatidylcholine, a phospholipid constituent of the cell membrane, its uptake, and processing for construction and maintenance of the cell membrane is a possible explanation for its accumulation in hyperfunctioning parathyroid glands [76, 77]. Stimulation of phospholipid-dependent choline-kinase results in increased radiolabeled choline uptake and is related to the secretion of PTH in HPT [78].

A commonly used choline analogue in clinical practice is ( N - [ $\left({ }^{18} \mathrm{~F}\right)$ fluoromethyl $]-2-$ hydroxy - N , N dimethylethanaminium $\left(\left[{ }^{18} \mathrm{~F}\right] \mathrm{FCH}\right.$ or $\left[{ }^{18} \mathrm{~F}\right]$ fluorocholine $)$. Other similar radiofluorinated choline derivatives are also available and supposedly show similar clinical behavior and utility. Administered activity ranges from 100 to $300 \mathrm{MBq}$ or $1.5-3.2 \mathrm{MBq} / \mathrm{kg}$ of body mass. According to the study by Rep et al., the recommended imaging time is one hour after the administration of the radiopharmaceutical, and, if possible, preceded by imaging acquired $5 \mathrm{~min}$ after the injection (starting as dynamic acquisition and followed by static), as some lesions may show uptake in the early phase only [79]. One acquisition $20 \mathrm{~min}$ after injection with delayed images in case of a negative result is also an option [40]. The field of view can be limited from the nose to the chest down to the base of the heart as for scintigraphy, to obtain a low radiation exposure from CT. But thanks to the more rapid acquisition with PET than with SPECT it may easily be extended to the whole torso or the whole body according to the patient's history (neoplasia, skeletal disease, infection...) or incidental findings. On PET/CT machines with incremental acquisition and time of flight imaging, at least $2 \mathrm{~min}$ per bed position may be recommended. PET/CT with ${ }^{18} \mathrm{~F}$-labeled choline analogues yields promising results, with DRs exceeding $90 \%$.

Treglia et al. in a meta-analysis of 14 choline studies (containing 12 studies with ${ }^{18} \mathrm{~F}$-labeled and 2 with ${ }^{11} \mathrm{C}$-labeled choline derivatives) involving 517 patients, reported pooled values for the sensitivity of $95 \%$, PPV $97 \%$, and DR $91 \%$ on a per-patient analysis. In a per-lesion analysis, the pooled sensitivity was $92 \%$ and PPV was $92 \%$ [78].

In addition, Hocevar et al. in a recent study demonstrated that patients with a single adenoma on $\left[{ }^{18} \mathrm{~F}\right]$ fluorocholine $\mathrm{PET} / \mathrm{CT}$ can safely and accurately undergo minimally invasive parathyroidectomy without intraoperative PTH testing
[80]. Preoperative localization was reliable in $96.8 \%$ of patients.

In a recent head to head comparative study including 103 patients with pHPT, the diagnostic performance of $\left[{ }^{18} \mathrm{~F}\right]$ fluorocholine PET/CT was superior to conventional scintigraphic methods $\left(\left[{ }^{99 \mathrm{~m}} \mathrm{Tc}\right] \mathrm{Tc}-\mathrm{MIBI}\right.$ SPECT/CT, $\left[{ }^{99 \mathrm{~m}} \mathrm{Tc}\right] \mathrm{Tc}-$ MIBI / Na $\left[{ }^{99 \mathrm{~m}} \mathrm{Tc}\right] \mathrm{TcO}_{4}$ subtraction imaging, and $\left[{ }^{99 \mathrm{~m}} \mathrm{Tc}\right] \mathrm{Tc}-$ MIBI dual-phase imaging), separately or combined, with a sensitivity of $92 \%$ for $\left[{ }^{18} \mathrm{~F}\right]$ fluorocholine PET/CT, compared with $39-56 \%$ for conventional imaging, and $65 \%$ for a combination of conventional methods [81]. The impact of the performance of the PET/CT machine on the performance of $\left[{ }^{18} \mathrm{~F}\right]$ fluorocholine imaging in patients with negative or inconclusive $\left[{ }^{99 \mathrm{~m}} \mathrm{Tc}\right] \mathrm{Tc}-\mathrm{MIBI}$ SPECT/CT has been recently assessed by Lopez-Mora et al. [82]. In a prospective series of 33 patients with pHPT confirmed at surgery, they found that $\left[{ }^{18} \mathrm{~F}\right]$ fluorocholine PET/CT employing an analogic scanner could detect hyperfunctioning tissue in 22 of 33 of patients with negative or inconclusive $\left[{ }^{99 \mathrm{~m}} \mathrm{Tc}\right] \mathrm{Tc}-\mathrm{MIBI}$ SPECT/CT, while a digital scanner detected hyperfunctioning tissue in 30 of 33 patients. The lesions detected only by the digital system were $<10 \mathrm{~mm}$ in diameter on resection, highlighting the potential importance of new PET/CT technologies in the detection of small parathyroid lesions.

Other advantages of PET/CT with ${ }^{18} \mathrm{~F}$-labeled choline analogues over $\left[{ }^{99 \mathrm{~m}} \mathrm{Tc}\right] \mathrm{Tc}-\mathrm{MIBI}$ scintigraphy are the lower radiation exposure [83], the higher resolution, and the shorter acquisition time. It is therefore considered an alternative first-line imaging method [84, 85].

Potential disadvantages of PET/CT with ${ }^{18} \mathrm{~F}$-labeled choline analogues are higher costs, the uptake by inflammatory lymph nodes and thyroid nodules as a potential source of false-positive results [86], and local reimbursement and licensing issues.

${ }^{18} \mathrm{~F}$-labeled choline analogues may be also used in PET/ MRI systems. This novel method is promising in patients with inconclusive results of standard imaging techniques [87].

\section{$\left[{ }^{11} \mathrm{C}\right] 2$-hydroxy-N,N,N-trimethylethanamium $\left(\left[{ }^{11} \mathrm{C}\right] \mathrm{CH}\right)$}

As mentioned above, choline is a precursor of phosphatidylcholine, which may explain the fact that $\left[{ }^{11} \mathrm{C}\right] \mathrm{CH}$ shows strong uptake in hyperfunctioning parathyroid cells [76].

Noltes et al. tried to optimize the protocol for $\left[{ }^{11} \mathrm{C}\right] \mathrm{CH}$ $\mathrm{PET} / \mathrm{CT}$ imaging, taking into consideration the activity and image quality [88]. They retrospectively studied 21 patients with pHPT and suggested image acquisition 20 min after administration of $6.3 \mathrm{MBq} / \mathrm{kg}\left[{ }^{11} \mathrm{C}\right] \mathrm{CH}$, with a scanning time of at least $5 \mathrm{~min}$. Orevi et al. in a prospective pilot study including 40 patients with $\mathrm{pHPT}$ indicated that $\left[{ }^{11} \mathrm{C}\right] \mathrm{CH}$ provides higher image quality than $\left[{ }^{99 \mathrm{~m}} \mathrm{Tc}\right] \mathrm{Tc}-\mathrm{MIBI}$, with the same or even superior diagnostic accuracy [89]. 
The advantage of $\left[{ }^{11} \mathrm{C}\right] \mathrm{CH}$ PET/CT over scintigraphy is a shorter acquisition time. There is fast uptake of $\left[{ }^{11} \mathrm{C}\right] \mathrm{CH}$ in hyperfunctioning parathyroid tissue, as well as a rapid clearance of background activity. Imaging is completed within $30 \mathrm{~min}$. In addition, the radiation exposure is lower. The short physical half-life of ${ }^{11} \mathrm{C}(20.3 \mathrm{~min})$ results in significantly lower radiation exposure than using a ${ }^{18} \mathrm{~F}$-labeled choline analogue, as well as other nuclear medicine techniques and 4DCT.

On the other hand, the short physical half-life is a drawback, restricting the use of ${ }^{11} \mathrm{C}$ to facilities with an on-site cyclotron. Additionally, a higher average positron energy of

${ }^{11} \mathrm{C}$ leads to more noise on the images and poorer spatial resolution compared with ${ }^{18} \mathrm{~F}$.

\section{L-[methyl $\left.-{ }^{11} \mathrm{C}\right]$ methionine $\left(\left[{ }^{11} \mathrm{C}\right] \mathrm{MET}\right)$}

$\left[{ }^{11} \mathrm{C}\right] \mathrm{MET}$ is a PET radiopharmaceutical that was previously often used as a second-line imaging tracer after negative or inconclusive conventional imaging. It is trapped in the hyperfunctioning parathyroid gland as it is involved in the synthesis of the PTH precursor [90]. The administered activity of the radiopharmaceutical varies between 370 and $1100 \mathrm{MBq}$ in different $\left[{ }^{11} \mathrm{C}\right]$ MET studies. Reported acquisition time is also highly variable, ranging from a start immediately after to $40 \mathrm{~min}$ after injection. In most studies, PET scanning is preceded or followed by a low-dose CT scan. Some authors recommend imaging at two time points, $10 \mathrm{~min}$ and $40 \mathrm{~min}$ after application of the radiopharmaceutical, preceded or followed by CT scanning for attenuation correction [90, 91]. The best parathyroid to cervical soft-tissue ratio was accomplished $10 \mathrm{~min}$ and the best parathyroid to thyroid ratio $40 \mathrm{~min}$ after administration of the radiopharmaceutical [90].

Increased uptake at early or late imaging is considered positive.

Kluijfhout et al. in a meta-analysis of $14\left[{ }^{11} \mathrm{C}\right] \mathrm{MET}$ studies found a pooled sensitivity of $77 \%$ and a pooled PPV of $98 \%$ for the detection of hyperfunctioning parathyroid glands in the correct quadrant [92]. There was no difference in sensitivity in patients with and without previous negative or inconclusive standard imaging ( $81 \%$ vs. $78 \%$, respectively). However, Noltes et al. in a recent retrospective study found that $\left[{ }^{11} \mathrm{C}\right] \mathrm{MET} \mathrm{PET} / \mathrm{CT}$ is able to identify parathyroid lesions on the correct side in only $64 \%(18 / 28)$ of patients after prior negative $\left[{ }^{99 \mathrm{~m}} \mathrm{Tc}\right] \mathrm{Tc}-\mathrm{MIBI}$ SPECT/CT and/or cUS [93].

Weber et al. prospectively studied whether $\left[{ }^{11} \mathrm{C}\right] \mathrm{MET}$ $\mathrm{PET} / \mathrm{CT}$ is able to identify $\left[{ }^{99 \mathrm{~m}} \mathrm{Tc}\right] \mathrm{Tc}-\mathrm{MIBI}$-negative hyperfunctioning parathyroid glands in a cohort of $50 \mathrm{pHPT}$ patients [94]. Pre-surgical scanning with $\left[{ }^{11} \mathrm{C}\right] \mathrm{MET}$ PET/CT localized hyperfunctioning parathyroid glands in $74 \%$ of patients with negative $\left[{ }^{99 \mathrm{~m}} \mathrm{Tc}\right] \mathrm{Tc}-\mathrm{MIBI}$ scintigraphy. $\left[{ }^{11} \mathrm{C}\right] \mathrm{MET}$ PET/CT detected 40 out of $57(70 \%)$ hyperfunctioning glands.
The major limitations of this radiopharmaceutical for more widespread use are the short physical half-life of ${ }^{11} \mathrm{C}$ (20.3 min) which necessitates an on-site cyclotron, the demanding labeling process which requires an on-site radiopharmacy with competent radiochemical staff, and a higher average positron energy which leads to more noise compared with ${ }^{18} \mathrm{~F}$. Additionally, there are local reimbursement and licensing issues.

\section{Other PET tracers}

Other PET tracers are not recommended for the detection of hyperfunctioning parathyroid glands, based on currently published data. ${ }^{18} \mathrm{~F}$-fluoro-D-glucose $\left(\left[{ }^{18} \mathrm{~F}\right] \mathrm{FDG}\right)$ is almost ubiquitously available and has the advantage of possible off-site usage due to a significantly longer physical half-life of ${ }^{18} \mathrm{~F}$ (110 min) compared with ${ }^{11} \mathrm{C}$. However, sensitivity and PPV vary considerably between the few available studies, $0-94 \%$ and $62-100 \%$, respectively. Therefore, this tracer does not seem suitable for the detection of hyperfunctioning parathyroid glands compared with other standard imaging techniques [92]. However, sometimes incidental parathyroid adenomas may be detected in $\left[{ }^{18} \mathrm{~F}\right] \mathrm{FDG}$ studies acquired for other reasons than HPT. 3,4-dihydroxy-6- $\left[{ }^{18} \mathrm{~F}\right]$ fluoro-L-phenylalanine $\left(6-\left[{ }^{18} \mathrm{~F}\right] \mathrm{F}-\mathrm{DOPA}\right)$ does not appear promising, as reported by Lange-Nolde et al. [95]. These authors scanned 8 patients with $\mathrm{pHPT}$ and histologically proven parathyroid adenomas, but none of the patients showed any detectable uptake of 6- $\left[{ }^{18} \mathrm{~F}\right]$ FDOPA in adenoma. O- $\left(2-\left[{ }^{18} \mathrm{~F}\right]\right.$ fluoroethyl)-L-tyrosine $\left(\left[{ }^{18} \mathrm{~F}\right] \mathrm{FET}\right)$ also does not appear to be promising as reported by Krakauer et al. [96]. In two patients, dual-isotope SPECT/CT located a parathyroid adenoma, verified by histopathology; only faint uptake of $\left[{ }^{18} \mathrm{~F}\right] \mathrm{FET}$ was detected in the hyperfunctioning parathyroid glands. The maximum (but low) target-to-background ratio was reached $30 \mathrm{~min}$ after tracer administration.

\section{Image analysis}

The reading of PET/CT or PET/MRI to localize hyperfunctioning parathyroid gland(s) usually starts with visualizing multiple intensity projections which may show foci behind the thyroid gland and help in detecting ectopic foci. The analysis of attenuation-corrected slices in the 3 planes with and without $\mathrm{CT}$ (or MRI) fusion is necessary in all cases, to precise the anatomical landmarking and the size of abnormal foci. The analysis of non-attenuation-corrected images may sometimes be useful in the case of artifacts on CT or of incidental foci in the lungs. For the neck region, the soft-tissue CT window should be used. A reading of PET and PET/CT (MRI) fused images of organs or structures out of the neck but included in the whole field of view, should not be omitted. The soft-tissue CT window is adapted to the mediastinum and the breasts 
(and the liver in the absence of a specific window), but other $\mathrm{CT}$ windows are recommended for lung and bone (and liver if this window is available).

All foci located from the upper neck to the base of the heart with an increased tracer uptake compared with the adjacent background should be considered. Focal accumulation of radiopharmaceutical in a nodule next to the thyroid is suspicious for a hyperfunctioning parathyroid gland in the loco typico. A hypodense character compared with the thyroid parenchyma on CT and a SUVmax greater than that of the thyroid parenchyma are further arguments favoring this interpretation [35]. In the case of dual-time point acquisition, the persistence in the late images of foci visible on the early images is a further argument in the case of equivocal early findings, but the disappearance of an evocative focus on early images could be due to a hyperfunctioning parathyroid gland with rapid clearance of the tracer. Even though the thyroid uptake of choline-based tracer is usually moderate, it is diffusely intense in case of thyroiditis or of Graves' disease, making the detection of foci adjacent to the thyroid gland difficult. The main interpretation problem is a focal tracer uptake inside the thyroid which corresponds in most cases to a malignant or benign thyroid nodule (in particular oxyphil adenomas are $\left[{ }^{18} \mathrm{~F}\right] \mathrm{FCH}$ avid) but may also correspond to an intrathyroidal parathyroid gland [35]. In methionine studies, thyroid nodules may also cause false-positive results [93]. In case of thyroid anomalies, it is recommended to analyze the PET/CT images with reference to thyroid scintigraphy (with $\mathrm{Na}\left[{ }^{123} \mathrm{I}\right] \mathrm{I}$ if available) to check how PET/CT foci match with the location and the iodine-metabolism of thyroid nodules; maximum intensity projection and coronal slices are particularly useful in this aim. Small thyroid remnants in case of partial or total thyroidectomy may take up the PET tracer leading to a false-positive result which may be avoided by referring to thyroid scintigraphy. Concerning the interpretation of ectopic foci, the main pitfall with metabolic tracers is uptake by reactive lymph nodes. In particular $\left[{ }^{18} \mathrm{~F}\right] \mathrm{FCH}$ is very frequently taken up by mediastinal and/or axillary lymph nodes which are not suspicious for ectopic parathyroid glands. Uptake by one single cervical lymphadenopathy may constitute a problem for interpretation [86]. The analysis of the CT (or MRI) component yields a more precise anatomical localisation and may also increase specificity.

False-negative results in choline/methionine studies may occur in cases of moderate hypercalcemia and non-elevated PTH serum levels (so-called "abnormally normal serum PTH level). In the case of MGD, one or several hyperplastic glands may be missed, particularly in sHPT or MEN. False-negative results may also be caused by a too restricted field of view, in particular in case of recurrence after parathyroidectomy.

\section{Reporting parathyroid radionuclide imaging}

The scan report should include patients' relevant identifying data as well as the relevant clinical history including serum PTH and calcium levels and any further relevant details, such as a history of MEN or history of (para)thyroid surgery.

The report should include a technical section, mentioning the protocol employed, the tracer(s) used together with administered activities and route of administration, which images were acquired (planar projections, SPECT/CT, PET/CT, PET/MRI, including the anatomic area), the dose-length product if $\mathrm{CT}$ has been acquired, and their respective timing and, if relevant, details on image reconstruction.

Reports need to include at least the description of abnormal findings (one or more hyperfunctioning parathyroid lesions) and localization of abnormal gland(s) expressed in terms of the four thyroidal quadrants including the gland(s) depth, or the particular ectopic location, as well as the images in which these are identified. Detection of a hyperfunctioning parathyroid gland with $\left[{ }^{99 \mathrm{~m}} \mathrm{Tc}\right] \mathrm{Tc}-\mathrm{MIBI}$, whose implantation in the forearm had not been recorded, was reported [97].

Additionally, one should document any incidental finding, such as pathological $\left[{ }^{99 \mathrm{~m}} \mathrm{Tc}\right] \mathrm{Tc}-\mathrm{MIBI}$ uptake in the pituitary region (if included in the field of view) [98], or in the lungs [99], or ${ }^{18}$ F-labeled choline analogues foci suspicious for malignancy [100, 101], which should prompt further diagnostic investigation. A frequently abnormal bone uptake of $\left[{ }^{99 \mathrm{~m}} \mathrm{Tc}\right] \mathrm{Tc}-\mathrm{MIBI}$ has been reported by Zhao et al. in 22 $(27.8 \%)$ patients [102]. Nineteen of them showed diffusely increased activity in the skeleton, 2 patients had focal uptake in brown tumors, and one showed both of these patterns. Brown tumors, also known as osteitis fibrosa cystica, are a specific complication of HPT, mostly in the case of sHPT or prolonged $\mathrm{pHPT}$, or parathyroid carcinoma. They are usually multiple, but also a solitary lesion may be present [103]. On CT, brown tumors appear as lytic or multilobular cystic changes. They may be detected with ${ }^{18} \mathrm{~F}$-labeled choline analogues whereas $\left[{ }^{99 \mathrm{~m}} \mathrm{Tc}\right] \mathrm{Tc}-\mathrm{MIBI}$ is negative [104]. In the case of incidental bone foci, this etiology may be considered as well as primary or secondary bone malignancies [105-107]. Diffuse and intense tracer uptake in the jaw may be observed in rare cases, being evocative of HPT-jaw tumor syndrome, a genetic disease linked with a negative prognosis [108-110].

\section{Cervical ultrasonography}

It is recommended to perform cUS in conjunction with nuclear medicine imaging. Cervical ultrasonography is often used for parathyroid gland localization. It is also utilized for confirming the diagnosis of the hyperfunctioning parathyroid gland(s) by guided FNA cytology and analysis of the FNAPTH in highly selected cases. It also provides an additional 
evaluation of the thyroid that may change surgical management, especially in the case of coexisting (suspected) malignant nodules [111].

Cervical ultrasonography is a low-cost, non-invasive (apart from guided FNA), accurate, and highly sensitive technique in experienced hands [112].

It is performed with the patient in a supine position with a hyperextended neck, using a high-frequency $(\geq 7 \mathrm{MHz})$ linear transducer. It is recommended to perform cross-sectional and longitudinal images of the anterior neck region, between the common carotid arteries, from the level of the carotid bifurcation down to the superior mediastinum, particularly paying attention to the posterior surface of the thyroid and the region below it. The size and location of the thyroid, thyroidal lesions, and any suspected parathyroid glands should be carefully documented. Owing to their small size (approximately 3 to $5 \mathrm{~mm}$ ), normal parathyroid glands are usually not identified on cUS. Hyperfunctioning parathyroid glands are detectable due to their size and echogenicity. They are usually hypoechoic, circumscribed, ovally shaped, delineated from the thyroid by hyperechoic connective tissue. However, they may have various shapes and contain fluid and, rarely, calcifications. Some glands have undergone cystic degeneration, presenting as anechoic lesions with dorsal echo amplification. Sometimes, a peripheral artery branching into the gland can be seen.

Occasionally it may be difficult to differentiate enlarged parathyroid glands from lymph nodes [33].

Cheung et al. in a meta-analysis of 19 studies found that cUS has a pooled sensitivity of $76.1 \%$ and a PPV of $93.2 \%$ in the preoperative localization of enlarged parathyroid glands in $\mathrm{pHPT}$ patients [113]. The diagnostic accuracy of ultrasound may be improved when performed after radionuclide imaging [114].

Cervical ultrasonography also has some limitations. It cannot detect ectopic parathyroid glands below the neck level VI and is less sensitive in the detection of small glands or MGD. Ruda et al. in a systematic review of 20,225 cases of pHPT found that the sensitivity of cUS in patients with two adenomas was $16.2 \%$ and in MGD 34.9\%, compared with $78.5 \%$ in single-gland disease [115]. Medas et al., in a retrospective study of 212 patients, also reported lower cUS sensitivity in patients with MGD compared with patients with single-gland disease ( $18.7 \%$ and $66.5 \%$, respectively) [59]. Haciyanli et al. reported accuracy of cUS of $40 \%$ in patients with two adenomas, while the combination of cUS and $\left[{ }^{99 \mathrm{~m}} \mathrm{Tc}\right] \mathrm{Tc}-\mathrm{MIBI}$ yielded an accuracy of $60 \%$ [116].

False-negative results also occur with an intrathyroidal location of hyperfunctioning parathyroid glands, being misinterpreted as thyroid nodules. Fine-needle aspiration cytology accompanied by the measurement of the FNA-PTH may solve this diagnostic challenge [117]. Furthermore, enlarged parathyroid glands adjacent to the upper thyroid poles may have a similar echogenicity as the thyroid gland and might hence be missed [112].
Medas et al. reported a lower sensitivity in patients with concomitant thyroid disease compared with patients with normal thyroid tissue ( $46.7 \%$ vs. $75 \%$ ) [59]. Thyroid nodules are a common reason for false-positive results, especially if located posteriorly [118]. This is an important issue since synchronous thyroid pathology is common in pHPT patients (18\% as reported by Bentrem et al.) [119].

For the reasons stated above, and since it is an operatordependent technique, it is recommended to combine cUS with parathyroid scintigraphy [73].

For FNA-PTH, a sensitivity of $70-100 \%$, and a specificity of $75-100 \%$ has been published, rendering it more reliable than cytology alone [120]. However, Trimboli et al. have shown that despite satisfactory results reported, this procedure is not widely used because it is not well standardized from preto post-analytical aspects. There is no consensus with regard to the FNA-PTH reference range and upper cut-off value. Some authors consider any FNA-PTH positive that is above the serum PTH level [121-124], whereas others suggest an FNA-PTH/serum PTH ratio of $\geq 2: 1$ in order to minimize the influence of sample contamination by blood [120].

However, in the case of non-diagnostic or indeterminate cytology findings, FNA-PTH might be useful.

Fine-needle aspiration may harbor complications, such as post-FNA fibrosis of the parathyroid gland and surrounding structures, making surgery more difficult and time-consuming [125]. It may also cause bedeviled histopathology by imitating malignancy. Norman et al. conducted a study that included 30 patients who underwent FNA of a parathyroid adenoma and a control group of 3000 patients who underwent surgery without previous FNA. On histopathology, adenomas in the control group showed a fibrotic reaction in $4.3 \%$ of cases, while glands with previous FNA had a fibrotic reaction in $77 \%$ of cases. The fibrotic reaction also imitated malignancy on histopathology. Additionally, the fibrotic reaction was more common with repeated FNA passes. Fine-needle aspiration was associated with a doubling of the surgery time [125]. Rarely, FNA may cause an inflammatory reaction, parathyroid abscess, or hematoma [126]. Very rare complications of FNA include parathyromatosis $[127,128]$ and the potential risk of parathyroid carcinoma seeding [129, 130]. For the reasons stated above, FNA cytology is recommended only in highly selected cases, e.g., atypical cUS findings, or inconclusive scintigraphy.

\section{Computed tomography}

Standard X-ray CT has limited value in the detection of enlarged parathyroid glands in pHPT [112].

Four-dimensional CT (4D-CT) consists of standard CT imaging with 3 vascular phases (non-enhanced, arterial, and venous), and the fourth dimension that allows enhancement 
evaluation over time $[131,132]$. Hence, this technique also provides functional data on enlarged parathyroid glands. Fast uptake and washout of contrast are considered typical for parathyroid adenomas [73].

This technique has similar diagnostic performance compared with [ ${ }^{99 \mathrm{~m}} \mathrm{Tc}$ ]Tc-MIBI SPECT [112], although protocols vary among institutions, which results in minor differences in DRs [133-135].

4D-CT has the advantage of short imaging time and is promising for the detection of small and ectopic parathyroid glands, but its drawbacks are comparably high radiation exposure and the need for iodinated contrast medium. The dose of radiation delivered to the thyroid is considerably higher than with standard imaging methods. Mahajan et al. reported a 57 times higher ( 92.0 vs. $1.6 \mathrm{mGy}$ ) thyroid dose compared with $\left[{ }^{99 m} \mathrm{Tc}\right] \mathrm{Tc}-\mathrm{MIBI}$ SPECT imaging [136]. As this at least in theory results in an increased risk for thyroid malignancies, this method should be used with caution, especially in younger patients. Some institutions perform fewer acquisitions to reduce radiation exposure. However, this in turn leads to a reduction in sensitivity. Kluijfhout et al. in a meta-analysis of 34 studies (2563 patients) found a lower pooled sensitivity of a single-contrast phase protocol (71\%), compared with 2and 3-contrast phase protocols ( $76 \%$ and $80 \%$, respectively) [137]. They suggested that a 2-contrast phase protocol is sufficient with regard to sensitivity and radiation exposure.

$4 \mathrm{D}-\mathrm{CT}$ is useful in the case of negative previous imaging studies or in patients with distorted neck anatomy. It is a good method for the preoperative detection of hyperfunctioning parathyroid glands after the unsuccessful initial surgery. Mortenson et al. in a prospective study of 45 patients who underwent parathyroid reoperation, revealed a higher sensitivity of 4D-CT compared with [ $\left.{ }^{99 \mathrm{~m}} \mathrm{Tc}\right] \mathrm{Tc}-\mathrm{MIBI}$ SPECT/CT and neck US $(88 \%, 54 \%$, and $21 \%$ respectively) [138].

Combined $\left[{ }^{18} \mathrm{~F}\right]$ fluorocholine PET and 4D contrastenhanced CT (4DCeCT) may be considered in pHPT patients with negative or inconclusive first-line imaging, as stated by Piccardo et al. [135]. They prospectively enrolled $44 \mathrm{pHPT}$ patients. $\left[{ }^{18} \mathrm{~F}\right]$ fluorocholine $\mathrm{PET} / 4 \mathrm{DCeCT}$ was positive in 32 of 44 patients with pHPT (72.7\%), and in 31 of 31 operated patients $(100 \%)$, being superior to $\left[{ }^{18} \mathrm{~F}\right]$ fluorocholine PET/CT alone ( $80 \%$ and $56.8 \%$, respectively) and $4 \mathrm{DCeCT}$ alone (74\% and $54.5 \%$, respectively).

However, the reported sensitivity of CT for a MGD is still as low as $32-53 \%$ [139].

\section{Magnetic resonance imaging}

Hyperfunctioning parathyroid glands may have variable MRI characteristics. However, they usually show intermediate to low signal intensity on T1-weighted images and high signal intensity on T2-weighted images [140].
Lopez Hänninen et al. in 2000 reported a high sensitivity of MRI for identifying hyperfunctioning parathyroid glands [141]. 1.5-T MRI detected 32 out of 39 surgically proven abnormal parathyroid glands (82\%). Sensitivity was higher for adenomas compared with hyperplasia $(87 \%$ and $75 \%$, respectively).

Wakamatsu et al. in a study from 2003, involving 35 patients with pHPT and 4 with sHPT, reported an unsatisfactory overall MRI sensitivity for the detection of hyperfunctioning parathyroid glands (43.4\%) [142]. There were 29 patients with the single-gland disease and 10 with MGD. The sensitivity for the first group was slightly higher $(48.3 \%$ vs. $37.5 \%$, respectively). However, they used a $0.5 \mathrm{~T}$ MRI, which may influence sensitivity.

A recent study by Argirò et al. demonstrated the correct localization of hyperfunctioning parathyroid glands in 45/46 patients that underwent $3 \mathrm{~T}$ MRI with standard clinical pulse sequences, yielded an excellent preoperative diagnostic performance, with a sensitivity of $97.8 \%$ and a specificity of 97.5\% [143]. Furthermore, it showed a good performance in MGD (8/8 enlarged glands detected) and ectopic parathyroid lesions (6/7 glands detected).

Merchavy et al. in a study from 2016 reported that 4D MRI is a useful technique for the preoperative detection of parathyroid lesions [144]. In 10 out of 11 patients with parathyroid lesions, 4D MRI localized adenomas correctly. The reported sensitivity was $90 \%$, and $100 \%$ after optimizing the imaging time. The specificity was $100 \%$.

Nowadays, MRI is mostly used as a second-line imaging technique.

While the use of gadolinium-based contrast agents is typically necessary, MRI does not carry any radiation exposure, which is a significant advantage of this technique. MRI is also used as part of PET/MRI exams with ${ }^{18} \mathrm{~F}$-labeled choline analogues and is considered particularly useful for the detection of cystic adenomas with comparably low tracer uptake [145, 146].

The use of MRI is limited in patients with kidney failure (if contrast medium is used) and implanted medical devices, such as cardiac pacemakers. Both kidney failure and cardiac arrhythmia are associated with HPT [76]. Furthermore, it may also be difficult for MRI to differentiate hyperfunctioning parathyroid glands from lymph nodes [142].

Further larger studies are necessary to confirm the diagnostic performance of MRI in this setting.

\section{Invasive diagnostic procedures}

Invasive diagnostic procedures are used in case of prior unsuccessful parathyroid surgery and negative or equivocal noninvasive imaging studies. They are rarely utilized nowadays due to improved standard non-invasive imaging and because 
they carry certain risks for the patient. Invasive techniques are associated with complications such as hematoma, contrastinduced nephropathy, and cerebrovascular infarction [73]. Anaphylaxis due to an allergic reaction to an iodinated contrast medium is an additional complication, also observed in non-invasive imaging $(\mathrm{CT})$. Thus, invasive techniques should be performed by a highly experienced operator.

\section{Selective venous sampling}

Selective venous sampling is the most commonly utilized technique. Serial blood samples are obtained from the superior vena cava, bilateral brachiocephalic, internal jugular, vertebral, thymic, superior, middle, and inferior thyroid veins [73]. An increase in PTH level from the vein drainage sites is compared with a peripheral sample. Ibraheem et al. in a recent meta-analysis of 12 studies found a pooled sensitivity and specificity of $74 \%$ and $41 \%$, respectively [147]. This method had a higher pooled sensitivity compared with noninvasive methods, mainly US and SPECT tracers, in reoperated patients.

\section{Selective arteriography}

Selective arteriography can be useful in patients with altered venous drainage due to prior neck surgery [73]. It is performed by selective transarterial induction of hypocalcemia in combination with nonselective venous sampling. An increase in PTH levels after stimulation is compared with baseline. A blush on the arteriogram is also considered a positive finding. Powell et al. in a study from 2009 found that arteriography is the best invasive procedure for localizing hyperfunctioning parathyroid glands (92\% PPV), before revision surgery [148].

\section{Open issues}

Primary hyperparathyroidism is usually caused by a solitary parathyroid adenoma, which is relatively easy to detect. However, in $15-20 \%$ of cases, it is caused by MGD, i.e., multiple adenomas or hyperplastic glands, which are more difficult to diagnose with SPECT/CT and PET/CT techniques, cUS, 4D-CT, and MRI. Additionally, in the last decades, there is a trend toward minimally invasive parathyroidectomy whenever possible, which may be another reason for missed MGD. However, in suspected MGD, not identified by standard techniques, open neck exploration should remain as an option. Another reason for failed imaging and unsuccessful surgery is an ectopic parathyroid gland. The reasons for imaging failure in this setting may be an inadequate imaging technique, failure to detect a rare ectopic site, as well as the imprecisely reported location of the ectopic gland. An additional problem, not only related to MGD and ectopic sites, is that not all hyperfunctioning parathyroid glands retain radiopharmaceuticals and the thyroid in certain cases does not show adequate washout. In these circumstances, dynamic or subtraction imaging might be helpful.

Another potential problem is a failure to detect ectopic glands in the pericardial region, due to the normal distribution of cardiotropic SPECT radiopharmaceuticals in neighboring myocardium. While these cases are extremely rare, they still need to be recognized.

Additional problems are caused by discordant imaging results. Novel techniques, such as PET/MRI with ${ }^{18}$ F-labeled choline analogues, appear to be promising in patients with inconclusive results of standard imaging techniques [87]. PET/MRI might be even more advantageous than PET/CT, owing to less radiation exposure and better soft-tissue contrast in the neck, improving the morphological correlation of PET findings. Current data exists from a few studies with up to 42 patients $[87,145,146,149]$, the majority of patients having negative or equivocal standard imaging.

Another rare but important issue is the imaging of parathyroid carcinoma and distinguishing it from benign parathyroid lesions. Parathyroid carcinoma is typically characterized by significant hypercalcemia and high PTH levels, but there are no specific biochemical features that allow for differentiation from benign parathyroid lesions. Several US features may be helpful in parathyroid carcinoma cases, such as larger lesion size $(>3 \mathrm{~cm})$, irregular lesion borders with tissue invasion, heterogeneous and decreased echogenicity, or tumor depth/with ratio of $\geq 1: 1$ [150]. Parathyroid carcinoma, its recurrences, and minimally invasive parathyroid carcinoma, usually accumulate $\left.{ }^{99 \mathrm{~m}} \mathrm{Tc}\right] \mathrm{Tc}-\mathrm{MIBI}$ [151-156], and recently it was demonstrated that parathyroid carcinoma has a higher retention level (mean and peak retention index) of [ $\left.{ }^{99 \mathrm{~m}} \mathrm{Tc}\right] \mathrm{Tc}-\mathrm{MIBI}$ compared with benign lesions [157], which may be helpful in the preoperative differential diagnosis. PET/CT with ${ }^{18} \mathrm{~F}$-labeled choline analogues is able to detect minimally invasive parathyroid carcinoma, according to recently published papers [154]. It may also detect local and distant recurrences of parathyroid carcinoma by their high uptake $[158,159] .\left[{ }^{18} \mathrm{~F}\right] \mathrm{FDG}$ PET/CT may also provide information on loco-regional and distant spreading, presumably in less well-differentiated lesions $[152,160]$. One isolated case of a $\left[{ }^{99 \mathrm{~m}} \mathrm{Tc}\right] \mathrm{Tc}-\mathrm{MIBI}-$ negative and $\left[{ }^{18} \mathrm{~F}\right]$ FDG-negative, but $\left[{ }^{11} \mathrm{C}\right] \mathrm{MET}$-positive parathyroid carcinoma local recurrence has been described [161]. Computed tomography and MRI are useful for detecting the local extent of disease, invasion of surrounding tissue, and distant spread. Fine-needle aspiration is not recommended in suspected parathyroid carcinoma, because cytology is not accurate in distinguishing malignant from benign lesions, and it may cause seeding of cancer cells [162]. 
Another issue is discussed in a recent article regarding the lack of specific criteria for the diagnosis of minimally invasive parathyroid carcinoma [154]. It appears to be less aggressive compared with "classic" parathyroid carcinoma and authors suggest the importance of differentiating it from parathyroid adenoma and parathyroid carcinoma.

\section{Conclusions}

The use of optimized first-line imaging for the detection and precise localization of hyperfunctioning parathyroid glands is important as the first operation is the best moment to obtain a long-lasting cure. Combining $\left[{ }^{99 \mathrm{~m}} \mathrm{Tc}\right] \mathrm{Tc}-\mathrm{MIBI}$ SPECT/CT with cUS performed by an experienced sonographer is a widely available and accepted first-line strategy. Different protocols exist for [ $\left.{ }^{99 \mathrm{~m}} \mathrm{Tc}\right] \mathrm{Tc}-\mathrm{MIBI}$ scintigraphy. Dual-phase imaging with SPECT/CT is a widely used technique. Dual-tracer subtraction imaging is a valuable alternative option. PET/CT with ${ }^{18} \mathrm{~F}$-labeled choline analogues has shown superior results; however, data from large cohorts and on costeffectiveness are not currently available. It may be considered a potential "alternative" first-line method whenever possible, as it appears to be an effective technique even in patients with negative/equivocal standard imaging findings. Other advantages of this technique are the high resolution, the low radiation exposure, and the shorter acquisition time. Modern sensitive PET/CT scanners and the use of PET/MRI for ${ }^{18} \mathrm{~F}$-labeled choline analogue imaging may result in significantly less radiation exposure compared with $\left[{ }^{99 \mathrm{~m}} \mathrm{Tc}\right] \mathrm{Tc}-\mathrm{MIBI}$ SPECT/CT. The drawbacks are higher costs compared with $\left[{ }^{99 \mathrm{~m}} \mathrm{Tc}\right] \mathrm{Tc}-\mathrm{MIBI}$, as well as local reimbursement and licensing issues. There are several second-line techniques available after negative or inconclusive first-line imaging. It is important to obtain concordant imaging by two techniques whenever possible. $\left[{ }^{11} \mathrm{C}\right] \mathrm{MET}$ is a radiopharmaceutical that may be used as a second-line PET imaging tracer as it has an excellent detection performance. However, major drawbacks of this radiopharmaceutical are the short physical half-life of ${ }^{11} \mathrm{C}$ which demands an on-site cyclotron, the demanding labeling process, poorer spatial resolution, local reimbursement, and licensing issues.

4D-CT may be useful in case of negative or inconclusive other imaging studies, in patients with distorted neck anatomy, or after futile surgery. It has similar diagnostic accuracy compared with $\left[{ }^{99 \mathrm{~m}} \mathrm{Tc}\right] \mathrm{Tc}-\mathrm{MIBI}$ SPECT, but a higher radiation exposure. ${ }^{18} \mathrm{~F}$-labeled choline analogue PET may be combined with 4D-CT in complicated cases (e.g., re-operated patients) to enhance the sensitivity and PPV compared with either technique alone. MRI may be also used after negative/ inconclusive first-line imaging or in pregnant patients. Invasive diagnostic procedures remain as last resort.

\section{Liability statement}

This guideline summarizes the views of the EANM Thyroid Committee. It reflects recommendations for which the EANM cannot be held responsible. The recommendations should be taken into context of good practice of nuclear medicine and do not substitute for national and international legal or regulatory provisions.

Acknowledgements The guidelines were brought to the attention of the relevant EANM Committees and the National Societies of Nuclear Medicine. The comments and suggestions from the EANM (Bone \& Joint, Oncology \& Theranostics, Paediatrics, Physics, Radiation Protection, Radiopharmacy, and Technologist Committee) and the (Belgian, Croatian, Czech, Finnish, French, Irish, Lithuanian, Macedonian, Polish, Russian, Serbian, and Turkish) National Societies are highly appreciated and have been considered for this guideline.

Funding Open access funding provided by University Medical Center Rotterdam (Erasmus MC).

Open Access This article is licensed under a Creative Commons Attribution 4.0 International License, which permits use, sharing, adaptation, distribution and reproduction in any medium or format, as long as you give appropriate credit to the original author(s) and the source, provide a link to the Creative Commons licence, and indicate if changes were made. The images or other third party material in this article are included in the article's Creative Commons licence, unless indicated otherwise in a credit line to the material. If material is not included in the article's Creative Commons licence and your intended use is not permitted by statutory regulation or exceeds the permitted use, you will need to obtain permission directly from the copyright holder. To view a copy of this licence, visit http://creativecommons.org/licenses/by/4.0/.

\section{References}

1. Silverberg SJ, Lewiecki EM, Mosekilde L, Peacock M, Rubin MR. Presentation of asymptomatic primary hyperparathyroidism: proceedings of the third international workshop. J Clin Endocrinol Metab. 2009 Feb [cited 2019 Nov 30];94(2):351-65. Available from: http://www.ncbi.nlm.nih.gov/pubmed/19193910.

2. Cetani F, Marcocci C, Torregrossa L, Pardi E. Atypical parathyroid adenomas: challenging lesions in the differential diagnosis of endocrine tumors. Endocr Relat Cancer. 2019;26(7):R441-64.

3. Fraser WD. Hyperparathyroidism. Lancet. 2009 Jul 11 [cited 2019 Oct 28];374(9684):145-58. Available from: http://www.ncbi.nlm. nih.gov/pubmed/19595349.

4. Bilezikian JP, Bandeira L, Khan A, Cusano NE. Hyperparathyroidism. Lancet (London, England). 2018 Jan 13 [cited 2019 Nov 7];391(10116):168-78. Available from: http:// www.ncbi.nlm.nih.gov/pubmed/28923463.

5. Duan K, Gomez Hernandez K, Mete O. Clinicopathological correlates of hyperparathyroidism. J Clin Pathol. 2015 Oct [cited 2019 Nov 7];68(10):771-87. Available from: http://www.ncbi. nlm.nih.gov/pubmed/26163537.

6. Almquist $\mathrm{M}$, Isaksson $\mathrm{E}$, Clyne $\mathrm{N}$. The treatment of renal hyperparathyroidism. Endocr Relat Cancer. 2020;27(1):R21-34.

7. Lau WL, Obi Y, Kalantar-Zadeh K. Parathyroidectomy in the management of secondary hyperparathyroidism. Clin J Am Soc 
Nephrol. 2018 Jun 7 [cited 2020 Jul 17];13(6):952-61. Available from: http://www.ncbi.nlm.nih.gov/pubmed/29523679.

8. Nakajima K, Tamai M, Okaniwa S, Nakamura Y, Kobayashi M, Niwa T, et al. Humoral hypercalcemia associated with gastric carcinoma secreting parathyroid hormone: a case report and review of the literature. Endocr J. 2013 [cited 2020 Aug 26];60(5): 557-62. Available from: http://www.ncbi.nlm.nih.gov/pubmed/ 23303131.

9. Taterra D, Wong LM, Vikse J, Sanna B, Pękala P, Walocha J, et al. The prevalence and anatomy of parathyroid glands: a metaanalysis with implications for parathyroid surgery. Langenbeck's Arch Surg. 2019 [cited 2020 Jun 12];404(1):63. Available from: https:/www.ncbi.nlm.nih.gov/pmc/articles/PMC6394670/.

10. Phitayakorn R, McHenry CR. Incidence and location of ectopic abnormal parathyroid glands. Am J Surg. 2006 Mar [cited 2019 Nov 7];191(3):418-23. Available from: http://www.ncbi.nlm.nih. gov/pubmed/16490559.

11. Akerström G, Malmaeus J, Bergström R. Surgical anatomy of human parathyroid glands. Surgery. 1984 Jan [cited 2019 Nov 30];95(1):14-21. Available from: http://www.ncbi.nlm.nih. gov/pubmed/6691181.

12. Wang C. The anatomic basis of parathyroid surgery. Ann Surg. 1976 Mar [cited 2019 Nov 30];183(3):271-5. Available from: http://www.ncbi.nlm.nih.gov/pubmed/1259483.

13. Taïeb D, Hassad R, Sebag F, Colavolpe C, Guedj E, Hindié E, et al. Tomoscintigraphy improves the determination of the embryologic origin of parathyroid adenomas, especially in apparently inferior glands: imaging features and surgical implications. J Nucl Med Technol. 2007 Sep 1 [cited 2020 Jun 15];35(3):135-9. Available from: http://tech.snmjournals.org/content/35/3/135. long.

14. Zerizer I, Parsaï A, Win Z, Al-Nahhas A. Anatomical and functional localization of ectopic parathyroid adenomas. Nucl Med Commun. 2011 Jun [cited 2019 Nov 29];32(6):496-502. Available from: http://www.ncbi.nlm.nih.gov/pubmed/21412177.

15. Shen W, Düren M, Morita E, Higgins C, Duh QY, Siperstein AE, et al. Reoperation for persistent or recurrent primary hyperparathyroidism. Arch Surg. 1996 Aug [cited 2019 Nov 30];131(8): 861-7; discussion 867-9. Available from: http://www.ncbi.nlm. nih.gov/pubmed/8712911.

16. Yadav R, Mohammed T-LH, Neumann DR, Mihaljevic T, Hoschar A. Case of the season: ectopic parathyroid adenoma in the pericardium: a report of robotically assisted minimally invasive parathyroidectomy. Semin Roentgenol. 2010 Jan [cited 2019 Nov 30];45(1):53-6. Available from: http://www.ncbi.nlm.nih. gov/pubmed/19944253.

17. Long KL, Lee CY, Ramaiah C, Sloan DA. Intrapericardial parathyroid adenoma $\dagger$. J Surg case reports. 2013 Aug 29 [cited 2019 Nov 30];2013(8). Available from: http://www.ncbi.nlm.nih.gov/ pubmed/24964470.

18. Ritter CS, Haughey BH, Miller B, Brown AJ. Differential gene expression by oxyphil and chief cells of human parathyroid glands. J Clin Endocrinol Metab. 2012 Aug [cited 2019 Nov 29];97(8):E1499-505. Available from: http://www.ncbi. nlm.nih.gov/pubmed/22585091.

19. Brown MB, Limaiem F. Histology, Parathyroid Gland. StatPearls. StatPearls Publishing; 2019 [Cited 2019 Nov 29]. Available from: http://www.ncbi.nlm.nih.gov/pubmed/31536203.

20. Hayakawa N, Nakamoto Y, Kurihara K, Yasoda A, Kanamoto N, Miura M, et al. A comparison between 11C-methionine PET/CT and MIBI SPECT/CT for localization of parathyroid adenomas/ hyperplasia. Nucl Med Commun. 2015 Jan [cited 2019 Aug 27];36(1):53-9. Available from: http://content.wkhealth. $\mathrm{com} /$ linkback/openurl?sid=WKPTLP:landingpage \&an= 00006231-201501000-00008.
21. Sukan A, Reyhan M, Aydin M, Yapar AF, Sert Y, Canpolat T, et al. Preoperative evaluation of hyperparathyroidism: the role of dual-phase parathyroid scintigraphy and ultrasound imaging. Ann Nucl Med. 2008 Feb 3 [cited 2019 Nov 8];22(2):123-31. Available from: http://www.ncbi.nlm.nih.gov/pubmed/18311537.

22. Patel CN, Salahudeen HM, Lansdown M, Scarsbrook AF. Clinical utility of ultrasound and $99 \mathrm{mTc}$ sestamibi SPECT/CT for preoperative localization of parathyroid adenoma in patients with primary hyperparathyroidism. Clin Radiol. 2010 Apr [cited 2019 Nov 8];65(4):278-87. Available from: http://www.ncbi.nlm.nih. gov/pubmed/20338394.

23. Castellana M, Virili C, Palermo A, Giorgino F, Giovanella L, Trimboli P. Primary hyperparathyroidism with surgical indication and negative or equivocal scintigraphy: safety and reliability of PTH washout. A systematic review and meta-analysis. Eur J Endocrinol. 2019 Sep 1 [cited 2020 Aug 3];181(3):245-53. Available from: http://www.ncbi.nlm.nih.gov/pubmed/31311003.

24. Chen Y-H, Chen H-T, Lee M-C, Liu S-H, Wang L-Y, Lue K-H, et al. Preoperative F-18 fluorocholine PET/CT for the detection of hyperfunctioning parathyroid glands in patients with secondary or tertiary hyperparathyroidism: comparison with Tc-99m sestamibi scan and neck ultrasound. Ann Nucl Med. 2020;1-11. Available from: https://doi.org/10.1007/s12149-020-01479-2.

25. Talbot J-N, Zhang-Yin J, Delbot T, Tassart M, Anton I, Balogova $\mathrm{S}$, et al. Added value of fluorocholine $(\mathrm{FCH}) \mathrm{PET} / \mathrm{CT}$ to sestaMIBI scintigraphy/SPECT (Sc) and ultrasonography (US) for preoperatory detection of hyperfuntionning parathyroid (PT) glands in patients with hyperparathyroidism (HPT) and chronic kidney disease (CKD). Eur J Nucl Med Mol Imaging. 2019 [cited 2020 Jul 14];46(Suppl 1):S552-553 OP - 116. Available from: https://posterng.netkey.at/eanm/viewing/index.php?module $=$ viewing_poster\&task $=\& \mathrm{pi}=4030$.

26. Huellner MW, Aberle S, Sah B-R, Veit-Haibach P, Bonani M, Schmid C, et al. Visualization of parathyroid hyperplasia using $18 \mathrm{~F}$-fluorocholine PET/MR in a patient with secondary hyperparathyroidism. Clin Nucl Med. 2016 Mar [cited 2020 Aug 3];41(3):e159-61. Available from: http://www.ncbi.nlm. nih.gov/pubmed/26462047.

27. Singh Ospina NM, Rodriguez-Gutierrez R, Maraka S, Espinosa de Ycaza AE, Jasim S, Castaneda-Guarderas A, et al. Outcomes of parathyroidectomy in patients with primary hyperparathyroidism: a systematic review and meta-analysis. World J Surg. 2016 Oct [cited 2020 Aug 3];40(10):2359-77. Available from: http://www. ncbi.nlm.nih.gov/pubmed/27094563.

28. Bilezikian JP, Brandi ML, Eastell R, Silverberg SJ, Udelsman R, Marcocci C, et al. Guidelines for the management of asymptomatic primary hyperparathyroidism: summary statement from the Fourth International Workshop. J Clin Endocrinol Metab. 2014 Oct 1 [cited 2020 Jun 13];99(10):3561-9. Available from: https://academic.oup.com/jcem/article-lookup/doi/10.1210/jc. 2014-1413.

29. Udelsman R, Lin Z, Donovan P. The superiority of minimally invasive parathyroidectomy based on 1650 consecutive patients with primary hyperparathyroidism. Ann Surg. 2011 Mar [cited 2020 Aug 3];253(3):585-91. Available from: http://www.ncbi. nlm.nih.gov/pubmed/21183844.

30. Udelsman R. Six Hundred Fifty-Six Consecutive Explorations for Primary Hyperparathyroidism. Ann Surg. 2002 [cited 2020 Apr 27];235(5):665. Available from: https://www.ncbi.nlm.nih. gov/pmc/articles/PMC1422492/.

31. Roy M, Mazeh H, Chen H, Sippel RS. Incidence and localization of ectopic parathyroid adenomas in previously unexplored patients. World J Surg. 2013 Jan [cited 2020 Aug 3];37(1):102-6. Available from: http://www.ncbi.nlm.nih.gov/pubmed/22968537.

32. Harari A, Mitmaker E, Grogan RH, Lee J, Shen W, Gosnell J, et al. Primary hyperparathyroidism patients with positive 
preoperative sestamibi scan and negative ultrasound are more likely to have posteriorly located upper gland adenomas (PLUGs). Ann Surg Oncol. 2011 [cited 2020 Jun 13];18(6):1717. Available from: https://www.ncbi.nlm.nih.gov/pmc/articles/ PMC3087871/.

33. Mohammadi A, Moloudi F, Ghasemi-rad M. The role of colour Doppler ultrasonography in the preoperative localization of parathyroid adenomas. Endocr J. 2012;59(5):375-82.

34. Isik S, Akbaba G, Berker D, Tutuncu YA, Ozuguz U, Aydin Y, et al. Thyroid-related factors that influence preoperative localization of parathyroid adenomas. Endocr Pract. 2012 [cited 2020 Aug 3];18(1):26-33. Available from: http://www.ncbi.nlm.nih. gov/pubmed/21742606.

35. Michaud L, Balogova S, Burgess A, Ohnona J, Huchet V, Kerrou $\mathrm{K}$, et al. A pilot comparison of $18 \mathrm{~F}$-fluorocholine PET/CT, ultrasonography and 123I/99mTc-sestaMIBI dual-phase dual-isotope scintigraphy in the preoperative localization of hyperfunctioning parathyroid glands in primary or secondary hyperparathyroidism: influence of thyroid anomalies. Medicine (Baltimore). 2015 Oct [cited 2020 Aug 23];94(41):e1701. Available from: http://www. ncbi.nlm.nih.gov/pubmed/26469908.

36. Taïeb D, Ureña-Torres P, Zanotti-Fregonara P, Rubello D, Ferretti A, Henter I, et al. Parathyroid scintigraphy in renal hyperparathyroidism: the added diagnostic value of SPECT and SPECT/CT. Clin Nucl Med. 2013 Aug [cited 2020 Apr 26];38(8):630-5. Available from: http://www.ncbi.nlm.nih.gov/pubmed/23751837.

37. Hindié E, Ureña-Torres PA, Taïeb D. Parathyroid imaging in patients with renal hyperparathyroidism. In: Parathyroid Glands in Chronic Kidney Disease. Cham: Springer International Publishing; 2020 [cited 2020 Jun 15]. p. 35-49. Available from: https://doi.org/10.1007/978-3-030-43769-5 3.

38. Périé S, Fessi H, Tassart M, Younsi N, Poli I, St Guily JL, et al. Usefulness of combination of high-resolution ultrasonography and dual-phase dual-isotope iodine 123/technetium Tc 99m sestamibi scintigraphy for the preoperative localization of hyperplastic parathyroid glands in renal hyperparathyroidism. Am J Kidney Dis. 2005 Feb [cited 2020 Aug 3];45(2):344-52. Available from: http://www.ncbi.nlm.nih.gov/pubmed/15685513.

39. Wilhelm SM, Wang TS, Ruan DT, Lee JA, Asa SL, Duh Q-Y, et al. The American Association of Endocrine Surgeons guidelines for definitive management of primary hyperparathyroidism. JAMA Surg. 2016 [cited 2019 Dec 1];151(10):959-68. Available from: http://www.ncbi.nlm.nih.gov/pubmed/27532368.

40. Gauthé M, Dierick-Gallet A, Delbot T, Bricaire L, Bertherat J, North M-O, et al. 18F-fluorocholine PET/CT in MEN1 patients with primary hyperparathyroidism. World J Surg. 2020 Jul 17 [cited $2020 \mathrm{Jul} 22$ ]; Available from: https://doi.org/10.1007/ s00268-020-05695-9.

41. Desiato V, Melis M, Bianco T, Rocca A, Amato M, Quarto G, et al. Minimally invasive radioguided parathyroid surgery: a literature review. Int J Surg. 2016 Apr 1 [cited 2021 Jan 16];28:S84 93. Available from: https://www.sciencedirect.com/science/ article/pii/S1743919115014223?via\%3Dihub.

42. ACR practice guideline for imaging pregnant or potentially pregnant adolescents and women with ionizing radiation. Article. 2008;1076(Revised 2008):23-37.

43. Mattsson S, Johansson L, Leide Svegborn S, Liniecki J, Noßke D, Riklund K, et al. ICRP publication 128: radiation dose to patients from radiopharmaceuticals: a compendium of current information related to frequently used substances. Ann ICRP. 2015;44(2_suppl):7-321.

44. Fuster D, Torregrosa J-V, Domenech B, Solà O, Martín G, Casellas J, et al. Dual-phase 99mTc-MIBI scintigraphy to assess calcimimetic effect in patients on haemodialysis with secondary hyperparathyroidism. Nucl Med Commun. 2009 Nov [cited 2020
Jun 16];30(11):890-4. Available from: http://www.ncbi.nlm.nih. gov/pubmed/19657304.

45. Friedman K, Somervell H, Patel P, Melton GB, Garrett-Mayer E, Dackiw APB, et al. Effect of calcium channel blockers on the sensitivity of preoperative 99mTc-MIBI SPECT for hyperparathyroidism. Surgery. 2004 Dec 1 [cited 2019 Oct 28];136(6):1199204. Available from: http://www.ncbi.nlm.nih.gov/pubmed/ 15657576.

46. Giovanella L, Avram AM, Iakovou I, Kwak J, Lawson SA, Lulaj E, et al. EANM practice guideline/SNMMI procedure standard for RAIU and thyroid scintigraphy. Eur J Nucl Med Mol Imaging. 2019 Nov 7 [cited 2019 Nov 22];46(12):2514-25. Available from: https://doi.org/10.1007/s00259-019-04472-8.

47. Roef M, Vogel W V. The effects of muscle exercise and bed rest on $[18 \mathrm{~F}]$ methylcholine PET/CT. Eur J Nucl Med Mol Imaging. 2011 Mar [cited 2019 Dec 12];38(3):526-30. Available from: http://www.ncbi.nlm.nih.gov/pubmed/20967443.

48. van der Molen AJ, Reimer P, Dekkers IA, Bongartz G, Bellin MF, Bertolotto M, et al. Post-contrast acute kidney injury - Part 1: Definition, clinical features, incidence, role of contrast medium and risk factors. Eur Radiol. 2018 Jul 9 [cited 2020 Jun 16];28(7):2845-55. Available from: https://doi.org/10.1007/ s00330-017-5246-5.

49. van der Molen AJ, Reimer P, Dekkers IA, Bongartz G, Bellin MF, Bertolotto M, et al. Post-contrast acute kidney injury. Part 2: risk stratification, role of hydration and other prophylactic measures, patients taking metformin and chronic dialysis patients. Eur Radiol. 2018 Jul 7 [cited 2020 Jun 16];28(7):2856-69. Available from: https://doi.org/10.1007/s00330-017-5247-4.

50. Ferlin G, Borsato N, Camerani M, Conte N, Zotti D. New perspectives in localizing enlarged parathyroids by technetiumthallium subtraction scan. J Nucl Med. 1983;24(5):438-41.

51. Coakley AJ, Kettle AG, Wells CP, O'Doherty MJ, Collins RE. 99Tcm sestamibi-a new agent for parathyroid imaging. Nucl Med Commun. 1989 Nov [cited 2019 Dec 9];10(11):791-4. Available from: http://www.ncbi.nlm.nih.gov/pubmed/2532313.

52. Hetrakul N, Civelek AC, Stagg CA, Udelsman R. In vitro accumulation of technetium-99m-sestamibi in human parathyroid mitochondria. Surgery. 2001 Dec [cited 2019 Nov 30];130(6):10118. Available from: http://www.ncbi.nlm.nih.gov/pubmed/ 11742331 .

53. Carpentier A, Jeannotte S, Verreault J, Lefebvre B, Bisson G, Mongeau CJ, et al. Preoperative localization of parathyroid lesions in hyperparathyroidism: relationship between technetium- $99 \mathrm{~m}$ MIBI uptake and oxyphil cell content. J Nucl Med. 1998 Aug [cited 2019 Dec 9];39(8):1441-4. Available from: http://www. ncbi.nlm.nih.gov/pubmed/9708524.

54. Pons F, Torregrosa J V, Fuster D. Biological factors influencing parathyroid localization. Nucl Med Commun. 2003 Feb [cited 2019 Dec 9];24(2):121-4. Available from: http://www.ncbi.nlm. nih.gov/pubmed/12548035.

55. O'Doherty MJ, Kettle AG, Wells P, Collins REC, Coakley AJ. Parathyroid imaging with technetium- $99 \mathrm{~m}$-sestamibi: preoperative localization and tissue uptake studies. J Nucl Med. 1992;33(3):313-8.

56. Palestro CJ, Tomas MB, Tronco GG. Radionuclide imaging of the parathyroid glands. Semin Nucl Med. 2005 Oct [cited 2019 Oct 27];35(4):266-76. Available from: http://www.ncbi.nlm.nih. gov/pubmed/16150247.

57. Treglia G, Sadeghi R, Schalin-Jäntti C, Caldarella C, Ceriani L, Giovanella L, et al. Detection rate of ${ }^{99 m}$ Tc-MIBI single photon emission computed tomography (SPECT)/CT in preoperative planning for patients with primary hyperparathyroidism: a metaanalysis. Head Neck. 2016 Apr 1 [cited 2019 Nov 7];38(S1): E2159-72. Available from: http://doi.wiley.com/10.1002/hed. 24027. 
58. Pata G, Casella C, Magri GC, Lucchini S, Panarotto MB, Crea N, et al. Financial and clinical implications of low-energy CT combined with 99mtechnetium-sestamibi SPECT for primary hyperparathyroidism. Ann Surg Oncol. 2011 Sep 16 [cited 2020 Aug 5];18(9):2555-63. Available from: https://doi.org/10.1245/ s10434-011-1641-3.

59. Medas F, Erdas E, Longheu A, Gordini L, Pisano G, Nicolosi A, et al. Retrospective evaluation of the pre- and postoperative factors influencing the sensitivity of localization studies in primary hyperparathyroidism. Int J Surg. 2016 Jan 1 [cited 2019 Nov 17];25: 82-7. Available from: https:/www.sciencedirect.com/science/ article/pii/S1743919115013631.

60. Nichols KJ, Tomas MB, Tronco GG, Palestro CJ. Sestamibi parathyroid scintigraphy in multigland disease. Nucl Med Commun. 2012 Jan [cited 2019 Nov 29];33(1):43-50. Available from: http:// www.ncbi.nlm.nih.gov/pubmed/22001718.

61. Apostolopoulos DJ, Houstoulaki E, Giannakenas C, Alexandrides $\mathrm{T}$, Spiliotis J, Nikiforidis G, et al. Technetium-99m-tetrofosmin for parathyroid scintigraphy: comparison to thalliumtechnetium scanning. J Nucl Med. 1998;39(8 SUPPL):1433-41.

62. Ishibashi M, Nishida H, Hiromatsu Y, Kojima K, Tabuchi E, Hayabuchi N. Comparison of technetium-99m-MIBI, technetium-99m-tetrofosmin, ultrasound and MRI for localization of abnormal parathyroid glands. J Nucl Med. 1998 Feb [cited 2019 Nov 30];39(2):320-4. Available from: http://www.ncbi.nlm.nih. gov/pubmed/9476944.

63. Wakamatsu H, Noguchi S, Yamashita H, Yamashita H, Tamura S, Jinnouchi S, et al. Technetium-99m tetrofosmin for parathyroid scintigraphy: a direct comparison with 99mTc-MIBI, 201Tl, MRI and US. Eur J Nucl Med. 2001 Dec 10 [cited 2019 Aug 28];28(12):1817-27. Available from: http://www.ncbi.nlm. nih.gov/pubmed/11734921.

64. Hindié E, Ugur Ö, Fuster D, O’Doherty M, Grassetto G, Ureña P, et al. 2009 EANM parathyroid guidelines. Eur J Nucl Med Mol Imaging. 2009;36(7):1201-16.

65. Krausz Y, Bettman L, Guralnik L, Yosilevsky G, Keidar Z, BarShalom R, et al. Technetium-99m-MIBI SPECT/CT in primary hyperparathyroidism. World J Surg. 2006 Jan 13 [cited 2019 Sep 18];30(1):76-83. Available from: https://doi.org/10.1007/s00268005-7849-2.

66. Lavely WC, Goetze S, Friedman KP, Leal JP, Zhang Z, GarretMayer E, et al. Comparison of SPECT/CT, SPECT, and planar imaging with single- and dual-phase $(99 \mathrm{~m}) \mathrm{Tc}$-sestamibi parathyroid scintigraphy. J Nucl Med. 2007 Jul 1 [cited 2019 Nov 7];48(7):1084-9. Available from: http://www.ncbi.nlm.nih. gov/pubmed/17574983.

67. Bhatt PR, Klingensmith WC, Bagrosky BM, Walter JC, McFann KK, McIntyre RC, et al. Parathyroid imaging with simultaneous acquisition of $99 \mathrm{mTc}-\mathrm{Sestamibi}$ and 123I: the relative merits of pinhole collimation and SPECT/CT. J Nucl Med Technol. 2015 Dec 1 [cited 2020 Jun 16];43(4):275-81. Available from: http:// tech.snmjournals.org/content/43/4/275.full.

68. Hindié E, Zanotti-Fregonara P, Tabarin A, Rubello D, Morelec I, Wagner $\mathrm{T}$, et al. The role of radionuclide imaging in the surgical management of primary hyperparathyroidism. J Nucl Med. 2015 May 1 [cited 2020 Jun 16];56(5):737-44. Available from: http:// jnm.snmjournals.org/content/56/5/737.long.

69. Asseeva P, Paladino NC, Guerin C, Castinetti F, VaillantLombard J, Abdullah AE, et al. Value of $123 \mathrm{I} / 99 \mathrm{mTc}$-sestamibi parathyroid scintigraphy with subtraction SPECT/CT in primary hyperparathyroidism for directing minimally invasive parathyroidectomy. Am J Surg. 2019 [cited 2020 Aug 3];217(1):10813. Available from: http://www.ncbi.nlm.nih.gov/pubmed/ 29980283.

70. Hindié E, Mellière D, Jeanguillaume C, Perlemuter L, Chéhadé F, Galle P. Parathyroid imaging using simultaneous double-window recording of technetium-99m-sestamibi and iodine-123. J Nucl Med. 1998 Jun [cited 2019 Nov 30];39(6):1100-5. Available from: http://www.ncbi.nlm.nih.gov/pubmed/9627353.

71. Krakauer M, Wieslander B, Myschetzky PS, Lundstrøm A, Bacher T, Sørensen CH, et al. A prospective comparative study of parathyroid dual-phase scintigraphy, dual-isotope subtraction scintigraphy, 4D-CT, and ultrasonography in primary hyperparathyroidism. Clin Nucl Med. 2016 Feb [cited 2020 Aug 3];41(2): 93-100. Available from: http://www.ncbi.nlm.nih.gov/pubmed/ 26447369.

72. Woods A-M, Bolster AA, Han S, Poon F-W, Colville D, Shand J, et al. Dual-isotope subtraction SPECT-CT in parathyroid localization. Nucl Med Commun. 2017 Dec [cited 2019 Dec 5];38(12): 1047-54. Available from: http://www.ncbi.nlm.nih.gov/pubmed/ 28984813.

73. Kunstman JW, Kirsch JD, Mahajan A, Udelsman R. Parathyroid localization and implications for clinical management. J Clin Endocrinol Metab. 2013 Mar 1 [cited 2019 Nov 14];98(3):90212. Available from: https://academic.oup.com/jcem/article/98/3/ 902/2536510.

74. Melloul M, Paz A, Koren R, Cytron S, Feinmesser R, Gal R. $99 \mathrm{mTc}-\mathrm{MIBI}$ scintigraphy of parathyroid adenomas and its relation to tumour size and oxyphil cell abundance. Eur J Nucl Med. 2001 Feb [cited 2020 Aug 3];28(2):209-13. Available from: http://www.ncbi.nlm.nih.gov/pubmed/11303892.

75. Eslamy HK, Ziessman HA. Parathyroid Scintigraphy in patients with primary hyperparathyroidism: $99 \mathrm{~m}$ Tc Sestamibi SPECT and SPECT/CT. RadioGraphics. 2008 Sep 1 [cited 2019 Dec 9];28(5): 1461-76. Available from: https://doi.org/10.1148/rg.285075055.

76. Parvinian A, Martin-Macintosh EL, Goenka AH, Durski JM, Mullan BP, Kemp BJ, et al. ${ }^{11}$ C-Choline PET/CT for detection and localization of parathyroid adenomas. Am J Roentgenol. 2018 Feb 15 [cited 2019 Nov 8];210(2):418-22. Available from: https://www.ajronline.org/doi/10.2214/AJR.17.18312.

77. Treglia G, Giovannini E, Di Franco D, Calcagni ML, Rufini V, Picchio M, et al. The role of positron emission tomography using carbon-11 and fluorine-18 choline in tumors other than prostate cancer: a systematic review. Ann Nucl Med. 2012 Jul 8 [cited 2020 Jun 13];26(6):451-61. Available from: https://doi.org/10. 1007/s12149-012-0602-7.

78. Treglia G, Piccardo A, Imperiale A, Strobel K, Kaufmann PA, Prior JO, et al. Diagnostic performance of choline PET for detection of hyperfunctioning parathyroid glands in hyperparathyroidism: a systematic review and meta-analysis. Eur J Nucl Med Mol Imaging. 2019 Mar 9 [cited 2019 Nov 11];46(3):751-65. Available from: https://doi.org/10.1007/s00259-018-4123-z.

79. Rep S, Lezaic L, Kocjan T, Pfeifer M, Sever MJ, Simoncic U, et al. Optimal scan time for evaluation of parathyroid adenoma with [(18)F]-fluorocholine PET/CT. Radiol Oncol. 2015 Dec [cited 2019 Nov 7];49(4):327-33. Available from: http://www.ncbi. nlm.nih.gov/pubmed/26834518.

80. Hocevar M, Lezaic L, Rep S, Zaletel K, Kocjan T, Sever MJ, et al. Focused parathyroidectomy without intraoperative parathormone testing is safe after pre-operative localization with $18 \mathrm{~F}$ Fluorocholine PET/CT. Eur J Surg Oncol. 2017 Jan [cited 2019 Nov 12];43(1):133-7. Available from: http://www.ncbi.nlm.nih. gov/pubmed/27776943.

81. Cuderman A, Senica K, Rep S, Hocevar M, Kocjan T, Sever MJ, et al. 18F-fluorocholine PET/CT in primary hyperparathyroidism: superior diagnostic performance to conventional scintigraphic imaging for localization of hyperfunctioning parathyroid glands. J Nucl Med. 2020 Apr [cited 2020 Jul 14];61(4):577-83. Available from: http://www.ncbi.nlm.nih.gov/pubmed/31562221.

82. López-Mora DA, Sizova M, Estorch M, Flotats A, Camacho V, Fernández A, et al. Superior performance of $18 \mathrm{~F}$-fluorocholine digital PET/CT in the detection of parathyroid adenomas. Eur $\mathrm{J}$ 
Nucl Med Mol Imaging. 2020 Mar 9 [cited 2020 Jun 12];47(3): 572-8. Available from: https://doi.org/10.1007/s00259-02004680-7.

83. Rep S, Hocevar M, Vaupotic J, Zdesar U, Zaletel K, Lezaic L. 18F-choline PET/CT for parathyroid scintigraphy: significantly lower radiation exposure of patients in comparison to conventional nuclear medicine imaging approaches. J Radiol Prot. 2018 [cited 2020 Jul 14];38(1):343-56. Available from: http://www.ncbi. nlm.nih.gov/pubmed/29339573.

84. Broos WAM, Wondergem M, Knol RJJ, van der Zant FM. Parathyroid imaging with $18 \mathrm{~F}$-fluorocholine PET/CT as a firstline imaging modality in primary hyperparathyroidism: a retrospective cohort study. EJNMMI Res. 2019 Dec 31 [cited 2019 Nov 7];9(1):72. Available from: https://ejnmmires.springeropen. com/articles/10.1186/s13550-019-0544-3

85. Giovanella L, Bacigalupo L, Treglia G, Piccardo A. Will 18Ffluorocholine PET/CT replace other methods of preoperative parathyroid imaging? Endocrine. 2021;71(2):285-97. Available from: http://www.ncbi.nlm.nih.gov/pubmed/32892309.

86. Imperiale A, Taïeb D, Hindié E. 18F-Fluorocholine PET/CT as a second line nuclear imaging technique before surgery for primary hyperparathyroidism. Eur J Nucl Med Mol Imaging. 2018 Apr 15 [cited 2019 Nov 7];45(4):654-7. Available from: https://doi.org/ 10.1007/s00259-017-3920-0.

87. Kluijfhout WP, Pasternak JD, Gosnell JE, Shen WT, Duh Q-Y, Vriens MR, et al. ${ }^{18} \mathrm{~F}$ Fluorocholine PET/MR Imaging in Patients with Primary Hyperparathyroidism and Inconclusive Conventional Imaging: A Prospective Pilot Study. Radiology. 2017 Aug 25 [cited 2020 Apr 21];284(2):460-7. Available from: https://doi.org/10.1148/radiol.2016160768.

88. Noltes ME, Kruijff S, Noordzij W, Telenga ED, Vállez García D, Trofimiuk-Müldner M, et al. Optimization of parathyroid 11Ccholine PET protocol for localization of parathyroid adenomas in patients with primary hyperparathyroidism. EJNMMI Res. 2019;9(1):73. Available from: http://www.ncbi.nlm.nih.gov/ pubmed/31367792.

89. Orevi M, Freedman N, Mishani E, Bocher M, Jacobson O, Krausz Y. Localization of parathyroid adenoma by ${ }^{11} \mathrm{C}$-choline PET/CT: preliminary results. Clin Nucl Med. 2014 Dec [cited 2019 Nov 13];39(12):1033-8. Available from: http://www.ncbi.nlm. nih.gov/pubmed/25290292.

90. Otto D, Boerner AR, Hofmann M, Brunkhorst T, Meyer GJ, Petrich T, et al. Pre-operative localisation of hyperfunctional parathyroid tissue with 11C-methionine PET. Eur J Nucl Med Mol Imaging. 2004 Oct 29 [cited 2019 Aug 27];31(10):1405-12. Available from: http://www.ncbi.nlm.nih.gov/pubmed/15278308.

91. Martínez-Rodríguez I, Martínez-Amador N, de Arcocha-Torres M, Quirce R, Ortega-Nava F, Ibáñez-Bravo S, et al. Comparison of $99 \mathrm{mTc}$-sestamibi and 11C-methionine PET/CT in the localization of parathyroid adenomas in primary hyperparathyroidism. Rev Esp Med Nucl Imagen Mol. 2014 [cited 2019 Dec 6];33(2): 93-8. Available from: http://www.ncbi.nlm.nih.gov/pubmed/ 24125595.

92. Kluijfhout WP, Pasternak JD, Drake FT, Beninato T, Gosnell JE, Shen WT, et al. Use of PET tracers for parathyroid localization: a systematic review and meta-analysis. Langenbeck's Arch Surg. 2016 Nov [cited 2019 Aug 27];401(7):925-35. Available from: http://www.ncbi.nlm.nih.gov/pubmed/27086309.

93. Noltes ME, Coester AM, van der Horst-Schrivers ANA, Dorgelo B, Jansen L, Noordzij W, et al. Localization of parathyroid adenomas using 11C-methionine pet after prior inconclusive imaging. Langenbeck's Arch Surg. 2017 Nov [cited 2019 Nov 10];402(7): 1109-17. Available from: http://www.ncbi.nlm.nih.gov/pubmed/ 28091771.

94. Weber T, Gottstein M, Schwenzer S, Beer A, Luster M. Is C-11 methionine $\mathrm{PET} / \mathrm{CT}$ able to localise sestamibi-negative parathyroid adenomas? World J Surg. 2017 Apr 10 [cited 2019 Dec 6];41(4):980-5. Available from: https://doi.org/10.1007/ s00268-016-3795-4.

95. Lange-Nolde A, Zajic T, Slawik M, Brink I, Reincke M, Moser E, et al. PET with $18 \mathrm{~F}-\mathrm{DOPA}$ in the imaging of parathyroid adenoma in patients with primary hyperparathyroidism. A pilot study. Nuklearmedizin. 2006 [cited 2019 Nov 9];45(5):193-6. Available from: http://www.ncbi.nlm.nih.gov/pubmed/17043728.

96. Krakauer M, Kjaer A, Bennedbæk FN. (18)F-FET-PET in primary hyperparathyroidism: a pilot study. Diagnostics (Basel, Switzerland). 2016 Aug 17 [cited 2019 Nov 9];6(3). Available from: http://www.ncbi.nlm.nih.gov/pubmed/27548229.

97. Ardito G, Revelli L, Giustozzi E, Giordano A. Radioguided parathyroidectomy in forearm graft for recurrent hyperparathyroidism. Br J Radiol. 2012 Jan [cited 2020 Aug 26];85(1009):e1-3. Available from: http://www.ncbi.nlm.nih.gov/pubmed/22190754.

98. Perez-Monte JE, Brown ML, Clarke MR, Watson CG, Carty SE. Parathyroid hyperplasia, thymic carcinoid and pituitary adenoma detected with technetium-99m-MIBI in MEN type I. J Nucl Med. 1997 Nov [cited 2016 Jun 27];38(11):1767-9. Available from: http://www.ncbi.nlm.nih.gov/pubmed/9374350.

99. Yapar Z, Kibar M, Sükan A, Paydas S, Zeren H, Inal M. Coincidental visualization of an atypical bronchial carcinoid on Tc-99m-sestamibi scan in Kallmann's syndrome. Ann Nucl Med. 2002 Feb [cited 2016 Jun 27];16(1):61-5. Available from: http:// www.ncbi.nlm.nih.gov/pubmed/11922210.

100. Kwee SA, DeGrado TR, Talbot JN, Gutman F, Coel MN. Cancer imaging with fluorine-18-labeled choline derivatives. Semin Nucl Med. 2007 Nov [cited 2020 Aug 20];37(6):420-8. Available from: http://www.ncbi.nlm.nih.gov/pubmed/17920349.

101. Hodolic M, Huchet V, Balogova S, Michaud L, Kerrou K, Nataf $\mathrm{V}$, et al. Incidental uptake of (18)F-fluorocholine (FCH) in the head or in the neck of patients with prostate cancer. Radiol Oncol. 2014 Sep [cited 2020 Aug 20];48(3):228-34. Available from: http://www.ncbi.nlm.nih.gov/pubmed/25177236.

102. Zhao Y, Wang Q. Bone uptake of Tc-99m MIBI in patients with hyperparathyroidism. Ann Nucl Med. 2014 May [cited 2020 Aug 20];28(4):349-55. Available from: http://www.ncbi.nlm. nih.gov/pubmed/24519437.

103. Wang X, Wang M, Zhang J, Zhu Y, Zhu M, Gao H, et al. Humeral brown tumor as first presentation of primary hyperparathyroidism caused by ectopic parathyroid adenomas: report of two cases and review of literature. Int J Clin Exp Pathol. 2014 Sep 15 [cited 2020 Aug 20];7(10):7094-9. Available from: http://www.ncbi.nlm.nih. gov/pubmed/25400803.

104. Zhang-Yin J, Gaujoux S, Delbot T, Gauthé M, Talbot J-N. 18FFluorocholine PET/CT Imaging of Brown Tumors in a Patient With Severe Primary Hyperparathyroidism. Clin Nucl Med. 2019 Dec 1 [cited 2020 Aug 20];44(12):971-4. Available from: http://www.ncbi.nlm.nih.gov/pubmed/31652163.

105. Phulsunga RK, Parghane RV, Kanojia RK, Gochhait D, Sood A, Bhattacharya A, et al. Multiple brown tumors caused by a parathyroid adenoma mimicking metastatic bone disease from giant cell tumor. World J Nucl Med. 2016 [cited 2020 Aug 21];15(1): 56-8. Available from: http://www.ncbi.nlm.nih.gov/pubmed/ 26912981.

106. Cassou-Mounat T, Balogova S, Nataf V, Calzada M, Huchet V, Kerrou K, et al. $18 \mathrm{~F}$-fluorocholine versus $18 \mathrm{~F}$ fluorodeoxyglucose for PET/CT imaging in patients with suspected relapsing or progressive multiple myeloma: a pilot study. Eur J Nucl Med Mol Imaging. 2016 Oct [cited 2020 Aug 21];43(11):1995-2004. Available from: http://www.ncbi. nlm.nih.gov/pubmed/27121691.

107. Leitha T, Glaser C, Pruckmayer M, Rasse M, Millesi W, Lang S, et al. Technetium-99m-MIBI in primary and recurrent head and 
neck tumors : contribution of bone SPECT image fusion. J Nucl Med. 1998;39(7):1166-71.

108. Piciu D, Piciu A, Barbus E, Pestean C, Larg MI, Fetica B. Primary hyperparathyroidism-jaw tumor syndrome: a confusing and forgotten diagnosis. Clujul Med. 2016 [cited 2020 Aug 21];89(4): 555-8. Available from: http://www.ncbi.nlm.nih.gov/pubmed/ 27857527.

109. Howell VM, Haven CJ, Kahnoski K, Khoo SK, Petillo D, Chen J, et al. HRPT2 mutations are associated with malignancy in sporadic parathyroid tumours. J Med Genet. 2003 Sep [cited 2020 Aug 21];40(9):657-63. Available from: http://www.ncbi.nlm. nih.gov/pubmed/12960210.

110. Torresan F, Iacobone M. Clinical Features, Treatment, and Surveillance of hyperparathyroidism-jaw tumor syndrome: an up-to-date and review of the literature. Int J Endocrinol. 2019 [cited 2020 Aug 23];2019:1761030. Available from: http:// www.ncbi.nlm.nih.gov/pubmed/31929790.

111. Kwon JH, Kim E-K, Lee HS, Moon HJ, Kwak JY. Neck ultrasonography as preoperative localization of primary hyperparathyroidism with an additional role of detecting thyroid malignancy. Eur J Radiol. 2013 Jan [cited 2019 Dec 1];82(1):e17-21. Available from: http://www.ncbi.nlm.nih.gov/pubmed/22921682.

112. Treglia G, Trimboli P, Huellner M, Giovanella L. Imaging in primary hyperparathyroidism: focus on the evidence-based diagnostic performance of different methods. Minerva Endocrinol. 2018;43(2):133-43.

113. Cheung K, Wang TS, Farrokhyar F, Roman SA, Sosa JA. A Metaanalysis of preoperative localization techniques for patients with primary hyperparathyroidism. Ann Surg Oncol. 2012 Feb 28 [cited 2019 Nov 14];19(2):577-83. Available from: http://www.ncbi. nlm.nih.gov/pubmed/21710322.

114. Kluijfhout WP, Vorselaars WMCM, Vriens MR, Borel Rinkes IHM, Valk GD, de Keizer B. Enabling minimal invasive parathyroidectomy for patients with primary hyperparathyroidism using Tc-99m-sestamibi SPECT-CT, ultrasound and first results of (18)F-fluorocholine PET-CT. Eur J Radiol. 2015;84(9):1745-51. Available from: http://www.ncbi.nlm.nih.gov/pubmed/26047823.

115. Ruda JM, Hollenbeak CS, Stack BC. A systematic review of the diagnosis and treatment of primary hyperparathyroidism from 1995 to 2003. Otolaryngol Head Neck Surg. 2005 Mar [cited 2020 Aug 3];132(3):359-72. Available from: http://www.ncbi. nlm.nih.gov/pubmed/15746845.

116. Haciyanli M, Lal G, Morita E, Duh Q-Y, Kebebew E, Clark OH. Accuracy of preoperative localization studies and intraoperative parathyroid hormone assay in patients with primary hyperparathyroidism and double adenoma. J Am Coll Surg. 2003 Nov [cited 2019 Dec 1];197(5):739-46. Available from: http://www.ncbi. nlm.nih.gov/pubmed/14585407.

117. Owens CL, Rekhtman N, Sokoll L, Ali SZ. Parathyroid hormone assay in fine-needle aspirate is useful in differentiating inadvertently sampled parathyroid tissue from thyroid lesions. Diagn Cytopathol. 2008 Apr [cited 2019 Nov 11];36(4):227-31. Available from: http://www.ncbi.nlm.nih.gov/pubmed/18335560.

118. Barbaros U, Erbil Y, Salmashoğlu A, Ișsever H, Aral F, Tunaci M, et al. The characteristics of concomitant thyroid nodules cause false-positive ultrasonography results in primary hyperparathyroidism. Am J Otolaryngol. 2009 [cited 2019 Dec 1];30(4):239 43. Available from: http://www.ncbi.nlm.nih.gov/pubmed/ 19563934

119. Bentrem DJ, Angelos P, Talamonti MS, Nayar R. Is preoperative investigation of the thyroid justified in patients undergoing parathyroidectomy for hyperparathyroidism? Thyroid. 2002 Dec [cited 2019 Dec 1];12(12):1109-12. Available from: http://www.ncbi. nlm.nih.gov/pubmed/12593724.
120. Trimboli P, D’Aurizio F, Tozzoli R, Giovanella L. Measurement of thyroglobulin, calcitonin, and PTH in FNA washout fluids. Clin Chem Lab Med. 2017;55(7):914-25.

121. Kuzu F, Arpaci D, Cakmak GK, Emre AU, Elri T, Ilikhan SU, et al. Focused parathyroidectomy without intra-operative parathormone monitoring: The value of PTH assay in preoperative ultrasound guided fine needle aspiration washout. Ann Med Surg. 2016 Mar [cited 2019 Nov 16];6:64-7. Available from: http:// www.ncbi.nlm.nih.gov/pubmed/26955476.

122. Bancos I, Grant C, Nadeem S, Stan M, Reading C, Sebo T, et al. Risks and benefits of parathyroid fine-needle aspiration with parathyroid hormone washout. Endocr Pract. 2012 Jul [cited 2019 Nov 16];18(4):441-9. Available from: http://journals.aace.com/ doi/abs/10.4158/EP11148.OR.

123. Abdelghani R, Noureldine S, Abbas A, Moroz K, Kandil E. The diagnostic value of parathyroid hormone washout after fine-needle aspiration of suspicious cervical lesions in patients with hyperparathyroidism. Laryngoscope. 2013 May [cited 2019 Nov 16];123(5):1310-3. Available from: http://www.ncbi.nlm. nih.gov/pubmed/23553068.

124. Giusti M, Dolcino M, Vera L, Ghiara C, Massaro F, Fazzuoli L, et al. Institutional experience of PTH evaluation on fine-needle washing after aspiration biopsy to locate hyperfunctioning parathyroid tissue. J Zhejiang Univ Sci B. 2009 May [cited 2019 Nov 16];10(5):323-30. Available from: http://www.ncbi.nlm. nih.gov/pubmed/19434758.

125. Norman J, Politz D, Browarsky I. Diagnostic aspiration of parathyroid adenomas causes severe fibrosis complicating surgery and final histologic diagnosis. Thyroid. 2007 Dec [cited 2020 Aug 4];17(12):1251-5. Available from: http://www.ncbi.nlm. nih.gov/pubmed/17887929.

126. Bancos I, Grant CS, Nadeem S, Stan MN, Reading CC, Sebo TJ, et al. Risks and benefits of parathyroid fine-needle aspiration with parathyroid hormone washout. Endocr Pract. 2012 [cited 2020 Aug 4];18(4):441-9. Available from: http://www.ncbi.nlm.nih. gov/pubmed/22784830.

127. Lentsch EJ, Withrow KP, Ackermann D, Bumpous JM. Parathyromatosis and recurrent hyperparathyroidism. Arch Otolaryngol Head Neck Surg. 2003 Aug [cited 2020 Aug 4];129(8):894-6. Available from: http://www.ncbi.nlm.nih. gov/pubmed/12925351.

128. Fitko R, Roth SI, Hines JR, Roxe DM, Cahill E. Parathyromatosis in hyperparathyroidism. Hum Pathol. 1990 Feb [cited 2020 Aug 4];21(2):234-7. Available from: http://www.ncbi.nlm.nih. gov/pubmed/2307452.

129. Spinelli C, Bonadio AG, Berti P, Materazzi G, Miccoli P. Cutaneous spreading of parathyroid carcinoma after fine needle aspiration cytology. J Endocrinol Invest. 2000 Apr [cited 2020 Aug 4];23(4):255-7. Available from: http://www.ncbi.nlm.nih. gov/pubmed/10853713.

130. Agarwal G, Dhingra S, Mishra SK, Krishnani N. Implantation of parathyroid carcinoma along fine needle aspiration track. Langenbeck's Arch Surg. 2006 Oct 27 [cited 2020 Apr 28];391(6):623-6. Available from: https://doi.org/10.1007/ s00423-006-0095-8.

131. Hoang JK, Williams K, Gaillard F, Dixon A, Sosa JA. Parathyroid 4D-CT: multi-institutional international survey of use and trends. Otolaryngol Head Neck Surg. 2016 [cited 2020 Aug 21];155(6): 956-60. Available from: http://www.ncbi.nlm.nih.gov/pubmed/ 27329424.

132. Bahl M, Sepahdari AR, Sosa JA, Hoang JK. Parathyroid Adenomas and hyperplasia on four-dimensional CT scans: three patterns of enhancement relative to the thyroid gland justify a three-phase protocol. Radiology. 2015 Nov [cited 2020 Aug 21];277(2):454-62. Available from: http://www.ncbi.nlm. nih.gov/pubmed/26024308. 
133. Yeh R, Tay Y-KD, Tabacco G, Dercle L, Kuo JH, Bandeira L, et al. Diagnostic performance of 4D CT and sestamibi SPECT/CT in localizing parathyroid adenomas in primary hyperparathyroidism. Radiology. 2019;291(2):469-76. Available from: https://doi. org/10.1148/radiol.2019182122.

134. Hinson AM, Lee DR, Hobbs BA, Fitzgerald RT, Bodenner DL, Stack BC. Preoperative 4D CT localization of nonlocalizing parathyroid adenomas by ultrasound and SPECT-CT. Otolaryngol Head Neck Surg. 2015 Nov 6 [cited 2020 Aug 21];153(5):7758. Available from: https://doi.org/10.1177/0194599815599372.

135. Piccardo A, Trimboli P, Rutigliani M, Puntoni M, Foppiani L, Bacigalupo L, et al. Additional value of integrated 18F-choline PET/4D contrast-enhanced CT in the localization of hyperfunctioning parathyroid glands and correlation with molecular profile. Eur J Nucl Med Mol Imaging. 2019 [cited 2020 Aug 4];46(3): 766-75. Available from: http://www.ncbi.nlm.nih.gov/pubmed/ 30219964.

136. Mahajan A, Starker LF, Ghita M, Udelsman R, Brink JA, Carling T. Parathyroid four-dimensional computed tomography: evaluation of radiation dose exposure during preoperative localization of parathyroid tumors in primary hyperparathyroidism. World J Surg. 2012 Jun [cited 2019 Dec 1];36(6):1335-9. Available from: http://www.ncbi.nlm.nih.gov/pubmed/22146947.

137. Kluijfhout WP, Pasternak JD, Beninato T, Drake FT, Gosnell JE, Shen WT, et al. Diagnostic performance of computed tomography for parathyroid adenoma localization; a systematic review and meta-analysis. Eur J Radiol. 2017 Mar [cited 2019 Dec 1];88: 117-28. Available from: http://www.ncbi.nlm.nih.gov/pubmed/ 28189196.

138. Mortenson MM, Evans DB, Lee JE, Hunter GJ, Shellingerhout D, $\mathrm{Vu}$ T, et al. Parathyroid exploration in the reoperative neck: improved preoperative localization with 4D-computed tomography. J Am Coll Surg. 2008 May [cited 2019 Dec 2];206(5):888-95; discussion 895-6. Available from: http://www.ncbi.nlm.nih.gov/ pubmed/18471717.

139. Sho S, Yuen AD, Yeh MW, Livhits MJ, Sepahdari AR. Factors Associated With discordance between preoperative parathyroid 4dimensional computed tomographic scans and intraoperative findings during parathyroidectomy. JAMA Surg. 2017 Dec 1 [cited 2019 Nov 12];152(12):1141. Available from: https://doi.org/10. 1001/jamasurg.2017.2649.

140. Kabala JE. Computed tomography and magnetic resonance imaging in diseases of the thyroid and parathyroid. Eur J Radiol. 2008 Jun [cited 2019 Dec 8];66(3):480-92. Available from: http:// www.ncbi.nlm.nih.gov/pubmed/18502599.

141. Lopez Hänninen E, Vogl TJ, Steinmüller T, Ricke J, Neuhaus P, Felix R. Preoperative contrast-enhanced MRI of the parathyroid glands in hyperparathyroidism. Invest Radiol. 2000 Jul [cited 2019 Dec 2];35(7):426-30. Available from: http://www.ncbi. nlm.nih.gov/pubmed/10901104.

142. Wakamatsu H, Noguchi S, Yamashita H, Yamashita H, Tamura S, Jinnouchi S, et al. Parathyroid scintigraphy with 99mTc-MIBI and 123I subtraction: a comparison with magnetic resonance imaging and ultrasonography. Nucl Med Commun. 2003 Jul [cited 2019 Dec 2];24(7):755-62. Available from: http://www.ncbi.nlm.nih. gov/pubmed/12813193.

143. Argirò R, Diacinti D, Sacconi B, Iannarelli A, Diacinti D, Cipriani $\mathrm{C}$, et al. Diagnostic accuracy of $3 \mathrm{~T}$ magnetic resonance imaging in the preoperative localisation of parathyroid adenomas: comparison with ultrasound and 99mTc-sestamibi scans. Eur Radiol. 2018 Nov 7 [cited 2019 Nov 13];28(11):4900-8. Available from: http:// www.ncbi.nlm.nih.gov/pubmed/29736849.

144. Merchavy S, Luckman J, Guindy M, Segev Y, Khafif A. 4D MRI for the localization of parathyroid adenoma. Otolaryngol Neck Surg. 2016 Mar 23 [cited 2019 Nov 13];154(3):446-8. Available from: https://doi.org/10.1177/0194599815618199.
145. Huber GF, Hüllner M, Schmid C, Brunner A, Sah B, Vetter D, et al. Benefit of $18 \mathrm{~F}$-fluorocholine PET imaging in parathyroid surgery. Eur Radiol. 2018 Jun [cited 2020 Aug 4];28(6):2700-7. Available from: http://www.ncbi.nlm.nih.gov/pubmed/29372312.

146. Alharbi AA, Alshehri FM, Albatly AA, Sah B-R, Schmid C, Huber GF, et al. [18F]Fluorocholine uptake of parathyroid adenoma is correlated with parathyroid hormone level. Mol imaging Biol. 2018 [cited 2020 Aug 4];20(5):857-67. Available from: http://www.ncbi.nlm.nih.gov/pubmed/29508264.

147. Ibraheem K, Toraih EA, Haddad AB, Farag M, Randolph GW, Kandil E. Selective parathyroid venous sampling in primary hyperparathyroidism: a systematic review and meta-analysis. Laryngoscope. 2018 [cited 2019 Dec 3];128(11):2662-7. Available from: http://www.ncbi.nlm.nih.gov/pubmed/29756350.

148. Powell AC, Alexander HR, Chang R, Marx SJ, Skarulis M, Pingpank JF, et al. Reoperation for parathyroid adenoma: a contemporary experience. Surgery. 2009 [cited 2020 Jul 18];146(6): 1144. Available from: https://www.ncbi.nlm.nih.gov/pmc/ articles/PMC3467310/

149. Krcma M. 18F-choline PET/MRI in patients with primary hyperparathyroidism and negative sestamibi SPECT/CT - report of two cases. Endocr Abstr. 2017 May 3 [cited 2020 Apr 21]; Available from: http://www.endocrine-abstracts.org/ea/0049/ea0049ep293. htm

150. Machado NN, Wilhelm SM. Parathyroid Cancer: a review. Cancers (Basel). 2019 Oct 28 [cited 2020 Aug 23];11(11). Available from: http://www.ncbi.nlm.nih.gov/pubmed/ 31661917

151. Alabed YZ, Rakheja R, Novales-Diaz JA, Lisbona R. Recurrent parathyroid carcinoma appearing as FDG negative but MIBI positive. Clin Nucl Med. 2014 Jul [cited 2020 Aug 23];39(7):e362-4. Available from: http://www.ncbi.nlm.nih.gov/pubmed/24458176.

152. Kim SS, Jeon YK, Lee SH, Kim BH, Kim SJ, Kim YK, et al. Distant subcutaneous recurrence of a parathyroid carcinoma: abnormal uptakes in the $99 \mathrm{mTc}$-sestamibi scan and 18F-FDG PET/ CT imaging. Korean J Intern Med. 2014 May [cited 2020 Aug 23];29(3):383. Available from: http://www.ncbi.nlm.nih. gov/pubmed/24851075.

153. Cao C, Dou C, Chen F, Wang Y, Zhang X, Lai H. An unusual mediastinal parathyroid carcinoma coproducing PTH and PTHrP: a case report. Oncol Lett. 2016 Jun [cited 2020 Aug 23];11(6): 4113-6. Available from: http://www.ncbi.nlm.nih.gov/pubmed/ 27313750 .

154. Singh P, Vadi SK, Saikia UN, Sood A, Dahiya D, Arya AK, et al. Minimally invasive parathyroid carcinoma-A missing entity between parathyroid adenoma and carcinoma: scintigraphic and histological features. Clin Endocrinol (Oxf). 2019 [cited 2020 Aug 23];91(6):842-50. Available from: http://www.ncbi.nlm. nih.gov/pubmed/31479153.

155. Haciyanli M, Oruk G, Ucarsoy AA, Gur O, Genc H. Multiglandular parathyroid carcinoma: case report and review of the literature. Endocr Pract. 2011 [cited 2020 Aug 23];17(4): e79-83. Available from: http://www.ncbi.nlm.nih.gov/pubmed/ 21454227.

156. Ferraro V, Sgaramella LI, Di Meo G, Prete FP, Logoluso F, Minerva F, et al. Current concepts in parathyroid carcinoma: a single Centre experience. BMC Endocr Disord. 2019 May 29 [cited 2020 Aug 23];19(S1):46. Available from: https://doi.org/10. 1186/s12902-019-0368-1.

157. Zhang M, Sun L, Rui W, Guo R, He H, Miao Y, et al. Semiquantitative analysis of $99 \mathrm{mTc}$-sestamibi retention level for preoperative differential diagnosis of parathyroid carcinoma. Quant Imaging Med Surg. 2019 Aug [cited 2020 Aug 23];9(8):1394401. Available from: http://qims.amegroups.com/article/view/ $27253 / 25102$. 
158. Morand GB, Rupp NJ, Huellner MW, Gerber PA, Soyka MB, Broglie MA, et al. Transnasal-transpterygoid endoscopic removal of an ${ }^{18} \mathrm{~F}$-choline-avid parathyroid carcinoma metastasis in the skull base. JAMA Otolaryngol Neck Surg. 2019 Oct 1 [cited 2020 Aug 23];145(10):978. Available from: https://jamanetwork.com/ journals/jamaotolaryngology/fullarticle/2748899.

159. Deandreis D, Terroir M, Al Ghuzlan A, Berdelou A, Lacroix L, Bidault $\mathrm{F}$, et al. 18Fluorocholine PET/CT in parathyroid carcinoma: a new tool for disease staging? Eur J Nucl Med Mol Imaging. 2015 Nov 9 [cited 2020 Aug 23];42(12):1941-2. Available from: https://doi.org/10.1007/s00259-015-3130-6.

160. Hatzl M, Röper-Kelmayr JC, Fellner FA, Gabriel M. 18FFluorocholine, 18F-FDG, and 18F-fluoroethyl tyrosine PET/CT in parathyroid cancer. Clin Nucl Med. 2017 Jun [cited 2020 Aug 23];42(6):448-50. Available from: http://www.ncbi.nlm. nih.gov/pubmed/28394837.

161. Omi Y, Yamamoto T, Nagashima Y, Abe K, Karasawa K, Tanaka $\mathrm{Y}$, et al. Parathyroid carcinoma in a 13-year-old girl with a longterm survival. Surg case reports. 2020 Jun 22 [cited 2020 Aug 23];6(1):145. Available from: http://www.ncbi.nlm.nih.gov/ pubmed/32572650.

162. Rodrigo JP, Hernandez-Prera JC, Randolph GW, Zafereo ME, Hartl DM, Silver CE, et al. Parathyroid cancer: an update. Cancer Treat Rev. 2020 Jun 1 [cited 2020 Aug 23];86:102012.
Available from: https://www.sciencedirect.com/science/article/ abs/pii/S0305737220300505.

163. Andersson M, Johansson L, Minarik D, Leide-Svegborn S, Mattsson S. Effective dose to adult patients from 338 radiopharmaceuticals estimated using ICRP biokinetic data, ICRP/ICRU computational reference phantoms and ICRP 2007 tissue weighting factors. EJNMMI Phys. 2014 Dec 29 [cited 2020 Jul 16];1(1):9. Available from: http://www.ncbi.nlm.nih.gov/ pubmed/26501451.

164. Mattsson S, Johansson L, Leide Svegborn S, Liniecki J, Noßke D, Riklund $\mathrm{K} \AA$, et al. Radiation dose to patients from radiopharmaceuticals: a compendium of current information related to frequently used substances. Ann ICRP. 2015 Jul 11 [cited 2020 Jul 23];44(2 Suppl):7-321. Available from: https://doi.org/10. $1177 / 0146645314558019$.

165. Tolvanen T, Yli-Kerttula T, Ujula T, Autio A, Lehikoinen P, Minn $\mathrm{H}$, et al. Biodistribution and radiation dosimetry of [(11)C $]$ choline: a comparison between rat and human data. Eur J Nucl Med Mol Imaging. 2010 May [cited $2020 \mathrm{Jul} 23$ ];37(5):874-83. Available from: http://www.ncbi.nlm.nih.gov/pubmed/20069295.

Publisher's note Springer Nature remains neutral with regard to jurisdictional claims in published maps and institutional affiliations. 